\title{
Improving the Urban Planning of the Green Zones in Al- Dammam Metropolitan Area, KSA, Using Integrated GIS location-allocation and Accessibility Models
}

\author{
Ashraf Abdelkarim \\ Research Center, Ministry of Housing, Riyadh, 84428, Saudi Arabia \\ Corresponding Author: dr.ashrafgis2020@gmail.com
}

Received 6 February 2020/ Revised 22 February 2020/ Accepted 1 March 2020/ Published 10 April 2020

\begin{abstract}
In the present study, the location-allocation and the accessibility models of GIS were integrated with the urban planning standards of the Ministry of Municipal and Rural affairs of Kingdom of Saudi Arabia (KSA) in order to enhance the spatial planning and the environmental sustainability of the green zones in Al-Dammam Metropolitan area, KSA. The integration of these models provides a framework for investigating the efficiency of the spatial distribution of the green zones and generating alternatives either by suggesting new effective service or by improving an existing one. To achieve these purposes, the accessibility within $(5,10$ and 15) minutes to the service areas in the green zones that is classified into nine types ("neighborhood gardens", "specialized parks", "cities gardens", "children's gardens", "district gardens", "streets and squares gardens", "sports city", "Sports clubs" and "Playgrounds") was analyzed through analyzing the network structure of the green zones in Al-Dammam Metropolitan area. The location-allocation model was used based on the maximum coverage within response time of no more than 10 minutes. The study revealed poor distribution of the green zones, the low per capita green zones rates with only $(3.52$ $\mathrm{m}^{2} /$ person) and there were no green zones in 45 districts representing $33.3 \%$ of the total districts in the investigated area. Consequently, Al-Dammam Metropolitan area suffers from the weakness of the green zones structure and the shortage in fulfilling the needs of population. The current needs were determined as nine services by two "sports cities", two "sports clubs", two "streets and Squares gardens", one "district garden", one "children's garden" and one "specialized park". It is recommended that the results of this study be taken into consideration by the decision makers while developing the urban planning strategies for improving the infrastructure efficiency as the KSA vision 2030.
\end{abstract}

Keywords: Urban planning; environmental sustainability; green zones; accessibility; locationallocation models; fair and efficient spatial distribution; KSA vision 2030.

\section{Introduction}

There is an increasing scientific recognition (Daniel et al.2017; Dinand and Sjerp 2017; Angela 2014; Dongkun \& Hyeyeong,2011) of the importance of the functional, recreational, environmental and health roles played by the open green zones in the people's 
life in the modern cities. It plays a vital role in reducing the air and audiovisual pollution and improving the local climatic conditions in cities. The open green zones exist not only to give a good view and reflect the welfare but also to provide many other environmental, psychological, social and visual benefits. This makes it one of the basic services that must be provided in a city.

Studying the green zones has gained the attention of many researchers in many aspects including; allotment gardens (Jürgen \& Martina 2015; Daniels \& Kirkpatrick 2006), green urban landscapes (Hand et al., 2016; Sarel et al., 2014), accessibility to green spaces (Dong et al.2015; Lina et al., 2017), general garden planning (Yuhong \& Jim 2011; Jim 2015), forest planning and management (Tenley \& Jennifer 2015; Liisa et al., 2001), national parks and demographic change (Greg et al.,2014; Mario et al.,2014), assessment of the spatial distribution efficiency of the green zones (Hao et al., 2017) and the modern techniques of the assessment and planning of the green zones (Root et al., 2017).

In the context of urban planning, green areas include different areas, such as parks, urban forests, nature reserves, waterways, playgrounds and other informal green areas (LA Rosa 2014; LA Rosa and Privitera 2013; Dai 2011) in this study the concept of green lands can be defined according to the Urban Planning Guide issued in May 2019 by the Ministry of Municipal and Rural Affairs in Saudi Arabia: it is a collection of unbuilt and abandoned lands for use as a breathing space for surrounding uses and urban blocks. The Ministry of Municipal and Rural Affairs has classified the green lands into nine main categories in its guide, namely: children's gardens, a nearby garden, and a garden, the neighborhood, the city park, the street gardens and squares, a specialized park (corniche), a playground, sports clubs, and a sports city which have been adopted in the current study.

Many studies (Rahman \& Smith, 1996; Fisher \& Rushton, 1979) have demonstrated the effect of site analysis in urban regional planning services. One of the most important methods is the accessibility and location-allocation modeling.

Accessibility is broad (Gould 1969) and the simple definition of accessibility is how fast or how far one has to go to reach a place, and refers to the spatial relationship, or degree of connection between this site and all other places in the region, although it is often defined as a relative proximity from one place to another (Yin \& Xu, 2009).

Accessibility analysis and location-allocation modeling studies provide a spatial quantitative information to evaluate the former local planning decisions and to generate 
alternatives either by suggesting new effective service systems or by improving the existing service systems, this is because the local planning decisions made by government or local leaders are often far from ideal.

The application of geographic analysis in services planning has been introduced in the recent years as a highly dynamic research area (Abdulkader, 2018). The application of the GIS accessibility and location-allocation models depends on the existence of spatial and demographic distribution in a specific manner and determining the demand locations based on specific criteria for selecting the best sites for services (Abdulkader, 2018). The minimum impedance and maximum coverage models are regarded the most efficient models for planning the green zones services (Daskin \& Dean 2004).

There is a growing interest in public urban green lands as one of the most important elements of sustainable urban planning around the world, simply because it provides important ecosystem services for urban dwellers, including recreational and sports activities. Most studies have shown that access to urban green lands is associated with increased wellbeing, physical health and social communication (De Vries et al., 2003; Maas et al., 2006; Kondo et al., 2018; Villeneuve et al. 2012; Wood et al., 2017; Wu et al., 2015) and reduced chronic job-related stress (Herrera et al.2018). In addition, urban green lands can support biodiversity (Strohbach et al., 2009; Dallimer et al., 2012), support a range of benefits known as ecosystem services (Tratalos et al.2007; Bolund \& Hunhammar, 1999), and mitigate the effects of urban heat island (Onishi et al., 2010).

Accessibility and location allocation were used as effective information to measure the efficiency of the spatial distribution of the transportation network and widely inequitable access to health services (Francisco et al., 2017), access to primary health care centers in Johannesburg (Hunadi, 2014), to allocate an improved site to earthquake relief centers (Bahram et al., 2018), to allocate the site to fire stations (Samira et al., 2018), spatial analysis of fire stations in India (Javaid et al., 2017), land planning (Geurs, 2004), urban planning (Zhong et al., 2016; Wei \& Yang, 2016), and tourism planning (Pan \& Cong 2012; Jin et al., 2010).

With regard to the application of accessibility and the allocation of sites in green areas, they were applied in the study of access to green areas of Shanghai (Fan et al., 2017), access to nearby greenery and human health (Dinand \& Sjerp, 2017), and the effects of population density on the quantity and structure of green spaces (Daniel et al., 2017), accessibility 
analysis for nearby gardens (Muge et al., 2016), citizen comfort analysis using accessibility to green areas(Lin et al., 2019), accessibility using land suitable for public parks in Larkana (Imtiaz et al., 2011), modelling of access for older people to green areas in high-density cities (Fangyinget al.2016), and planning urban green areas environmental network (Haifeng et al., 2015).

According to GIS modelling, GIS spatial modelling methods in GIS include buffer analysis(Li et al., 2016), analysis of the minimum approach distance (Yin et al., 2008), the gravitational indicator method (Hu et al., 2005; Zhou \& Guo, 2004), the cost resistance analysis (Ma \& Cao, 2006), analysis of possible spatial access to green area (Yin 2008; Li \& Liang, 2009; Ma \& Lu 2011; Zhoa et al., 2015).

Distance is a dominant aspect of accessibility indicators for nature or urban green lands, and the frequency of the effects of green land use decreases as the distance increases (Coombes et al., 2010). Most studies have confirmed that access to natural environments outside the home at a distance of 300 meters is associated positively with mental health indicators (Triguero-Mas et al., 2015), and in the United States the standard for walking is a mile or 400 meters at most (Sturm \& Cohen, 2014). The importance of access to nearby green lands was also recognized in the policy, with the European Environment Agency recommending that green lands must be accessible within a 15-minute walk from the residents' residence (Department for Environment Food and Rural Affairs 2019).

The urban planning for the use and management of the green zones is of exceptional importance especially in cities located in hot and dry latitudes like Al-Dammam metropolitan area. The green zones are regarded one of the planning treatment methods for creating suitable and comfortable climatic conditions for the population. The nature of the desert climate, the rapid increase in the population and urbanization particularly after the petroleum discovery, the increasing air and audiovisual pollution as a result of the development of the petroleum city and the resulting increase of human activities makes the existence, management and development of the green zones a necessity in the urban environment of AlDammam metropolitan area.

The present study aiming to improve the spatial urban planning of the green zones at AlDammam metropolitan area ensures that neglecting the planning of green zones based on integrating the standards of urban planning with the accessibility and location-allocation models leads to the misuse of the green zones. This may increase the inadequacy of the 
environment for fulfilling the environmental climatic and recreational needs of the population besides lowering the per capita rates of the green zones in Al-Dammam metropolitan area compared to other Arabian and international cities.

Compared to the previous studies, this study is distinguished by combining two of the most effective scientific methods in the process of evaluating and planning services and green areas. These are the accessibility method in information systems and site allocation models. This study was also distinguished from the other studies in that it applied local and international planning standards in assessing green areas. This study is also unique because it took into consideration 9 different types of green areas and did not depend only on one or two types, which gives the study a comprehensive characteristic in its handling of the topic of green areas. The previous studies also revealed the shortage of studies in the Arab library about the effective systematic integration of modern methods with geographic information systems in its handling of urban planning issues that put the green areas at the top of their priorities.

This study takes on special importance for a number of considerations, including the apparent lack of urban green lands research in the Arab regions in general and in the Saudi Arabian community in particular, unlike in the European and Northern American regions. Therefore, there is no opportunity to compare the locations of green lands that differ. There is no study in the field of the current research subject, which is the integration of accessibility models and the allocation of location in GIS in order to improve the spatial planning of green lands. Therefore, this study is unique as one of the first studies in the Arab Library that applies. It is also noticeable that there is a section of these studies that are listed in the context of previous studies which are consistent with the researcher's study in improving the spatial planning of health services by applying accessibility models and the allocation of location in GIS.However, it was applied to areas outside the Arab region. Moreover, this helps the methodology and methods used in this study to generalize the results to Urban planning models in other similar areas, in addition to demonstrating the true importance of GIS model studies in urban planning.

This study seeks to determine the efficiency of the spatial distribution of the green zones and its compatibility with the residential neighborhoods in Al-Dammam metropolitan area. It ensures the needed functional effectiveness and suggests new services based on modern unique approach through integrating the urban planning standards with the accessibility 
models. It aims to determine the efficiency and pattern of the distribution of the green zones with its various types through several analytical and statistical GIS techniques. This study also seeks to determine the current and future needs of the different types of green zones in Al-Dammam metropolitan area using the location-allocation technique.

\section{Area of Study}

Al-Dammam metropolitan area lies in the eastern province of KSA, at the Arabian Gulf coast between the waters of the Arabian Gulf and the dunes of Ad-Dahna desert. It is located between latitudes $26^{\circ} 06^{\prime} \mathrm{N}$ to $26^{\circ} 30^{\prime} \mathrm{N}$ and longitudes of $49^{\circ} 40^{\prime} \mathrm{E}$ to $50^{\circ} 15^{\prime} \mathrm{E}$. Administratively, it consists of three cities (Al-Dammam, Al-Khobar and Al-Dhahran) with total 135 neighborhoods and overall area of 59 thousand hectares. Al-Dammam metropolitan area is the third largest urban community in KSA as the population increased from 360 thousands in 1980 to 1.9 million in 2019. It is limited to the east and north east by the Arabian Gulf, to the south by Al Aziziah and Half Moon cities, to the north west by Sihat city, and to the west by Ad-Dahna desert. The general land slope in Al-Dammam metropolitan area is towards the gulf forming the so-called coastal plains (Figures 1, 2and 3).

One of the main features of Al-Dammam metropolitan area is the Arabian gulf coast that extends from the south to the north in the eastern and northeastern borders of the area forming a distinctive water front. Al-Dammam metropolitan area is dominated by the strip pattern that appears in the traditional planning designs of the new buildings of Al-Dammam and Al-Khobar cities. 
Ashraf Abdelkarim/ GEOSI Vol 5 No 1 (2020) 1-46

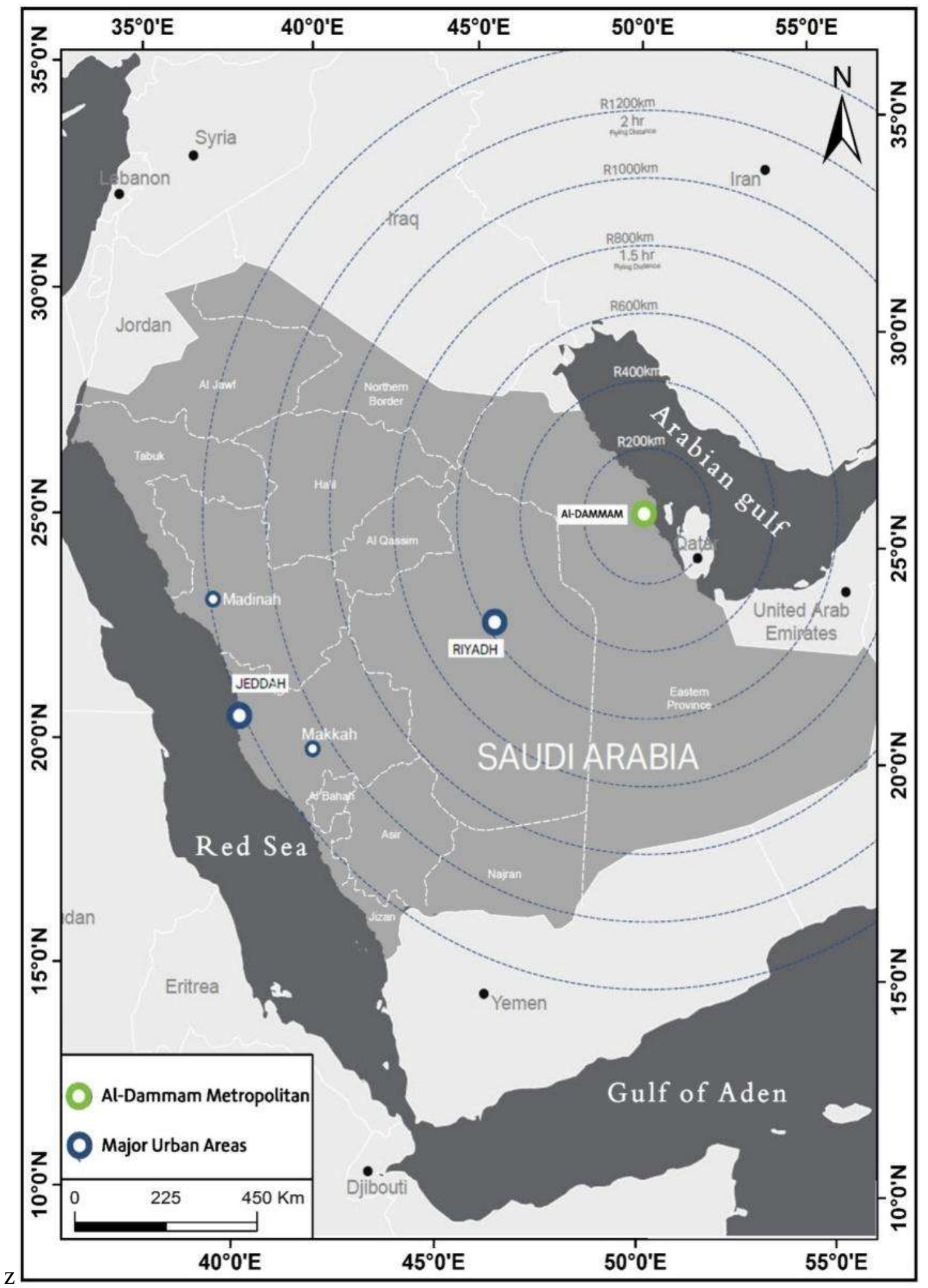

Figure 1. The location of AL-Dammam Metropolitan in the Kingdom of Saudi Arabia in 2019 
Ashraf Abdelkarim/ GEOSI Vol 5 No 1 (2020) 1-46

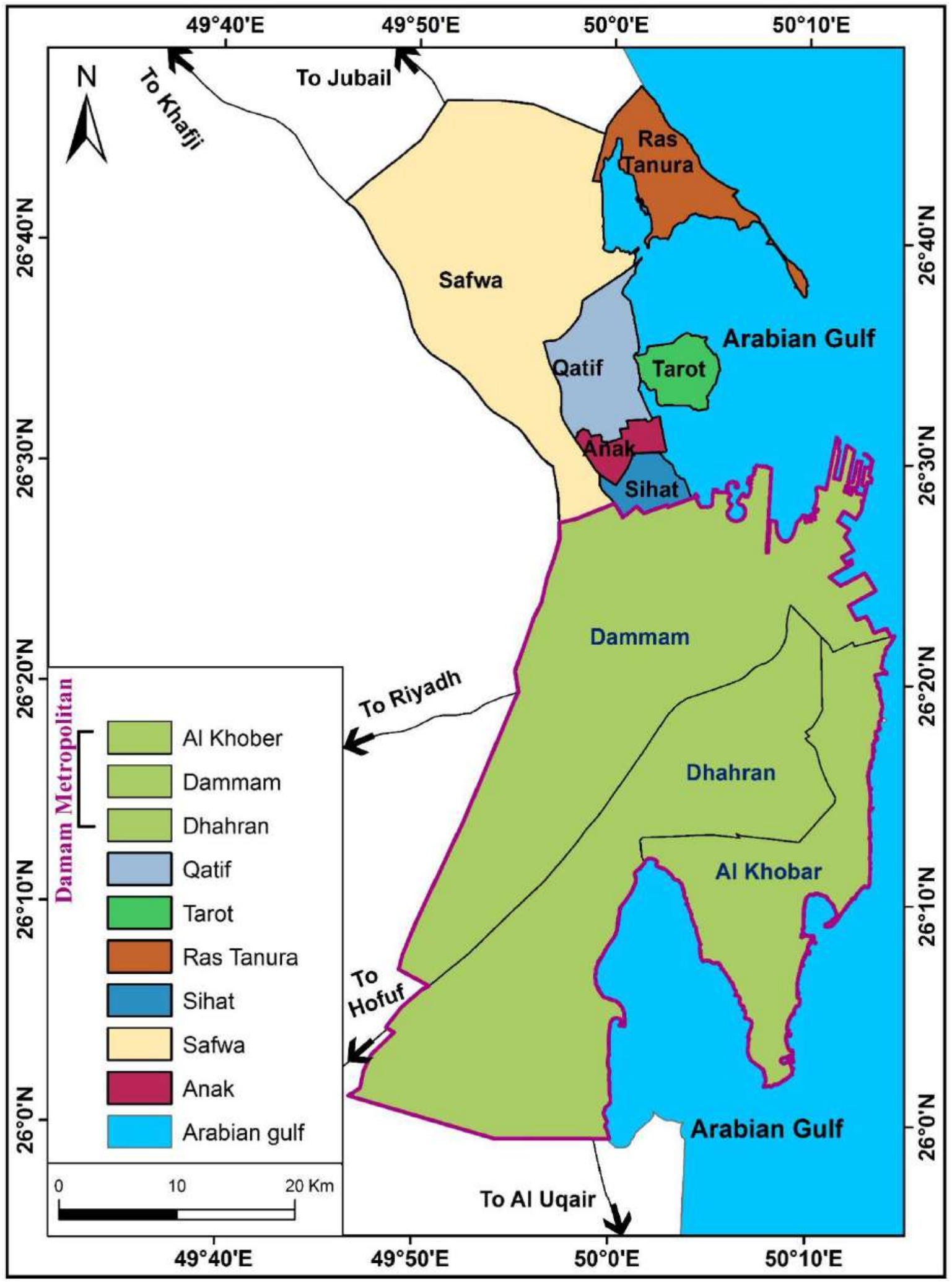

Figure 2. The location and administrative divisions of Al-Dammam metropolitan area as of year 2019 
Ashraf Abdelkarim/ GEOSI Vol 5 No 1 (2020) 1-46

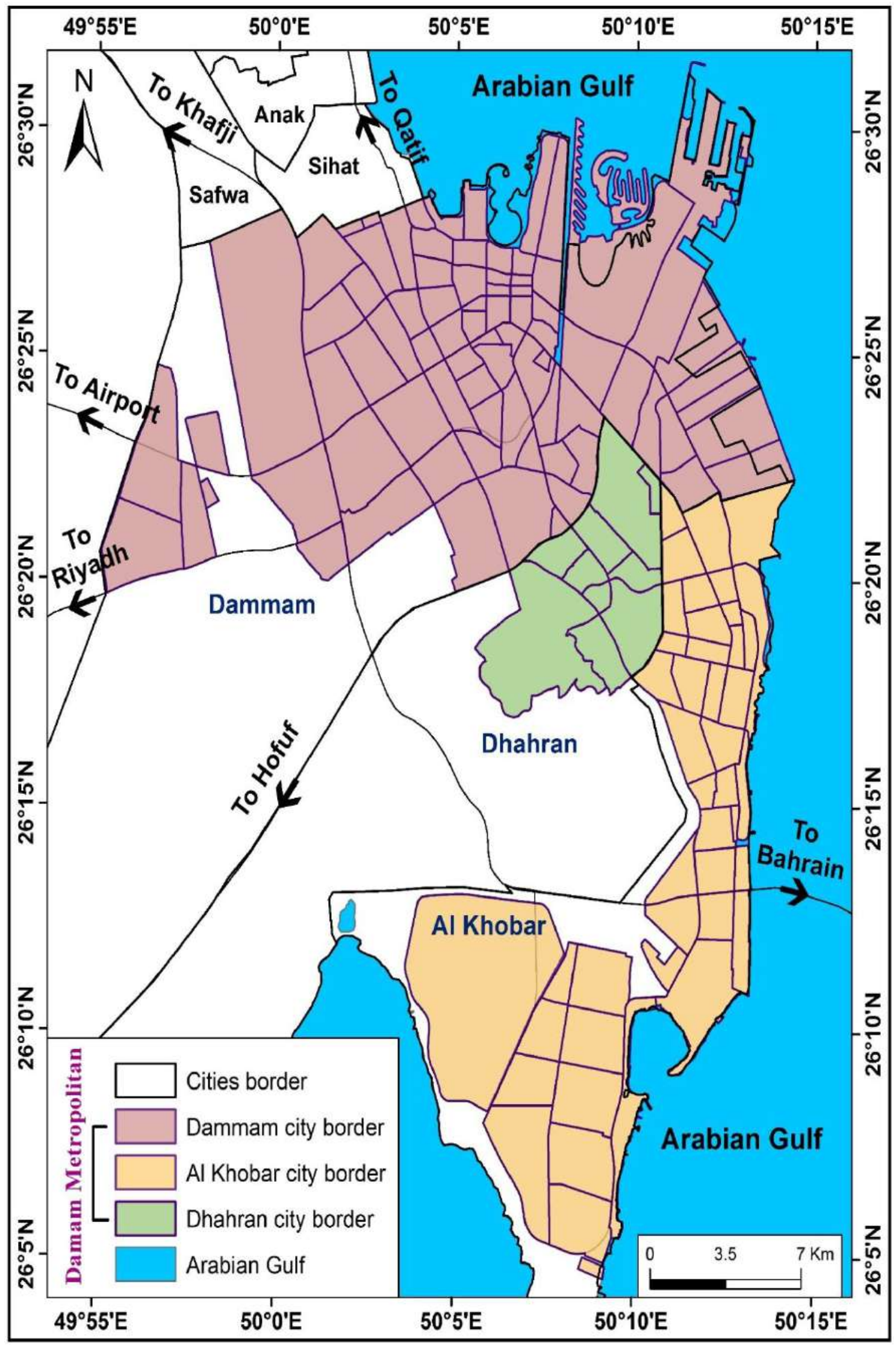

Figure 3. Districts of Al-Dammam metropolitan area as of year 2019 
The privilege of the location of Al-Dammam metropolitan area allowed it to be the center of economic and administrative growth in the eastern province of the KSA. AlDammam metropolitan area has very good transportation facilities, as it is linked to the other cities in the kingdom by a good transportation network. Internationally, Al-Dammam metropolitan area is not less than its competitors on the Arabian Gulf coast; Dubai, Abu Dhabi, Doha, Manama and Kuwait. Nationally, it is regarded as a main development center and a tourist attraction area for tourists from all over the kingdom and from the neighboring countries.

Al-Dammam metropolitan area is a major and vital source for petroleum oil in KSA and the world. It contains about $20 \%$ of the world's oil reserves. The petroleum sector in AlDammam metropolitan area gained extra importance after the discovery of large oil, natural gas reserves that are enough for over a century of production at the current rates. The petroleum industries have contributed significantly to the development of Al-Dammam metropolitan area, it led to an increase in the population and urbanization rates, expansion of the urban activities and lack of services of the green zones in the area.

\section{Methods}

This study combined the analysis of the accessibility to the green zones service areas to evaluate and to determine its coverage based on defined time intervals, with the locationallocation analysis. This also aims to plan the future of the green zones in Al-Dammam metropolitan area and determine the areas of deficiency and suggest new locations for services. GIS Network analysis is one of the most powerful tools used in this study as it is largely connected to the roads network which is the main transportation mean (ESRI, Arc GIS 2019). Other spatial and statistical analysis tools were also used for determining the green zones spatial distribution pattern.

The methodology of assessment and planning of the green zones in Al-Dammam metropolitan area has gone through five stages using the Arc GIS software (Figure4), as follows:

The first stage was collecting the required data for the surface network analysis including roads layer and service locations layer and other descriptive information such as information about the road segments (distance, time required, waiting time, speed and 
direction). All the collected data were projected by the same projection system to ensure that the results and outputs have the same ground projection.

The second stage was carrying out the "topology" on the roads layer in order to solve any spatial errors.

The third stage included building the attribute table and filling specified attributes with the corresponding descriptive data to act as weights when performing the surface network analysis.

The fourth stage included building the network data-set on the roads layer with filled attribute weights after being processed against the topology errors.

The fifth stage included performing the accessibility analysis based on service area analysis to evaluate the current standings of the green zones in Al-Dammam metropolitan area and to determine the coverage of services within time intervals of 5, 10 and 15minutes. The accessibility analysis is accessed from the network analysis toolbar in Arc GIS after activating it.

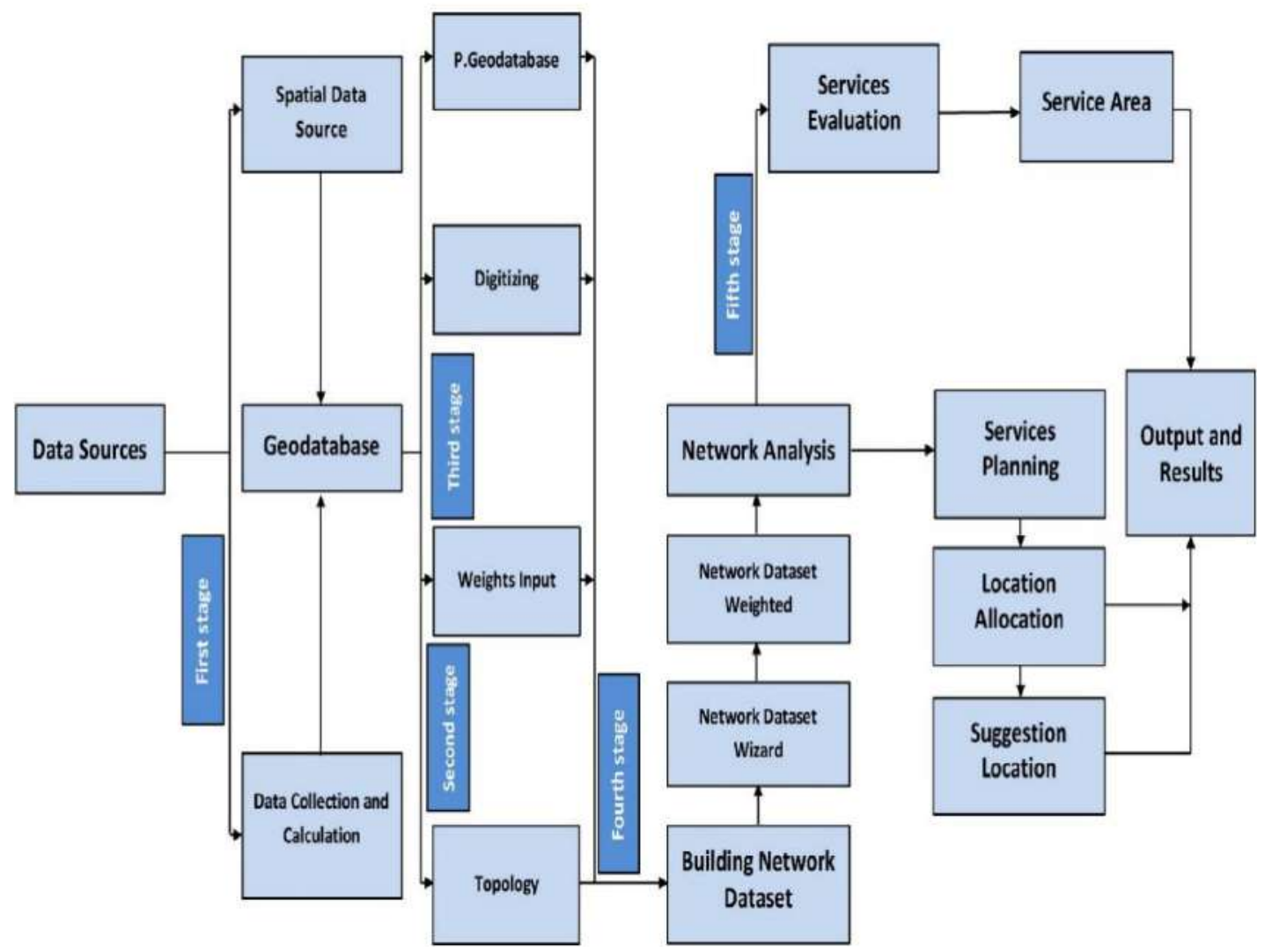

Figure 4.The adopted methodology and stages of the study 
The parameters of the accessibility analysis layer were defined as follows: the impedance weight attribute (distance or time), the outputs fit to the borders of the roads network layer using the "trim polygon" tool, and the output ranges merged using the "merge by default break" tool. After setting the parameters of the analysis layer and adding the layer of services locations (facilities) in the "Network Analysis Window", the output was obtained by solving the network using the "solve" tool. The output for all the administrative sections is then obtained for each section individually to determine the percentage of service coverage for each administrative section.Figure 5 illustrates the structure of the model of accessibility to the green zones in Al-Dammam metropolitan area.

The fifth stage also included performing the location-allocation analysis for planning the future of the green zones in Al-Dammam metropolitan area and for defining the areas of deficiency and suggesting new services. The location-allocation model is performed after building the roads network. It is accessed from the network analyst toolbar and it's parameters such as impedance weight attribute and value (distance or time), the number of facilities (facilities to choose), the impedance cutoff, and the location-allocation problem type. Figure 6 illustrates the structure of the location-allocation model for the green zones in Al-Dammam metropolitan area.

There are seven types of the location-allocation models (Hakimi1964), in the present study; the maximum coverage type was used (Rahman and Smith 1996) with the formula:

$$
\text { Maximize }\left\{F=\sum_{i \in I} \alpha_{i} x_{i}\right\}
$$

Where (I) is the group of demand points or the time duration or the population as weight, $\left(\mathrm{x}_{\mathrm{i}}\right)$ is the location-allocation parameter with either zero or one value only. After setting the parameters of the analysis layer and selecting the "maximize coverage" location-allocation type, the spatial locations of services (facilities) and the demand points were provided for the administrative sections of the study area and were represented by points layer in the Network Analysis Window. 


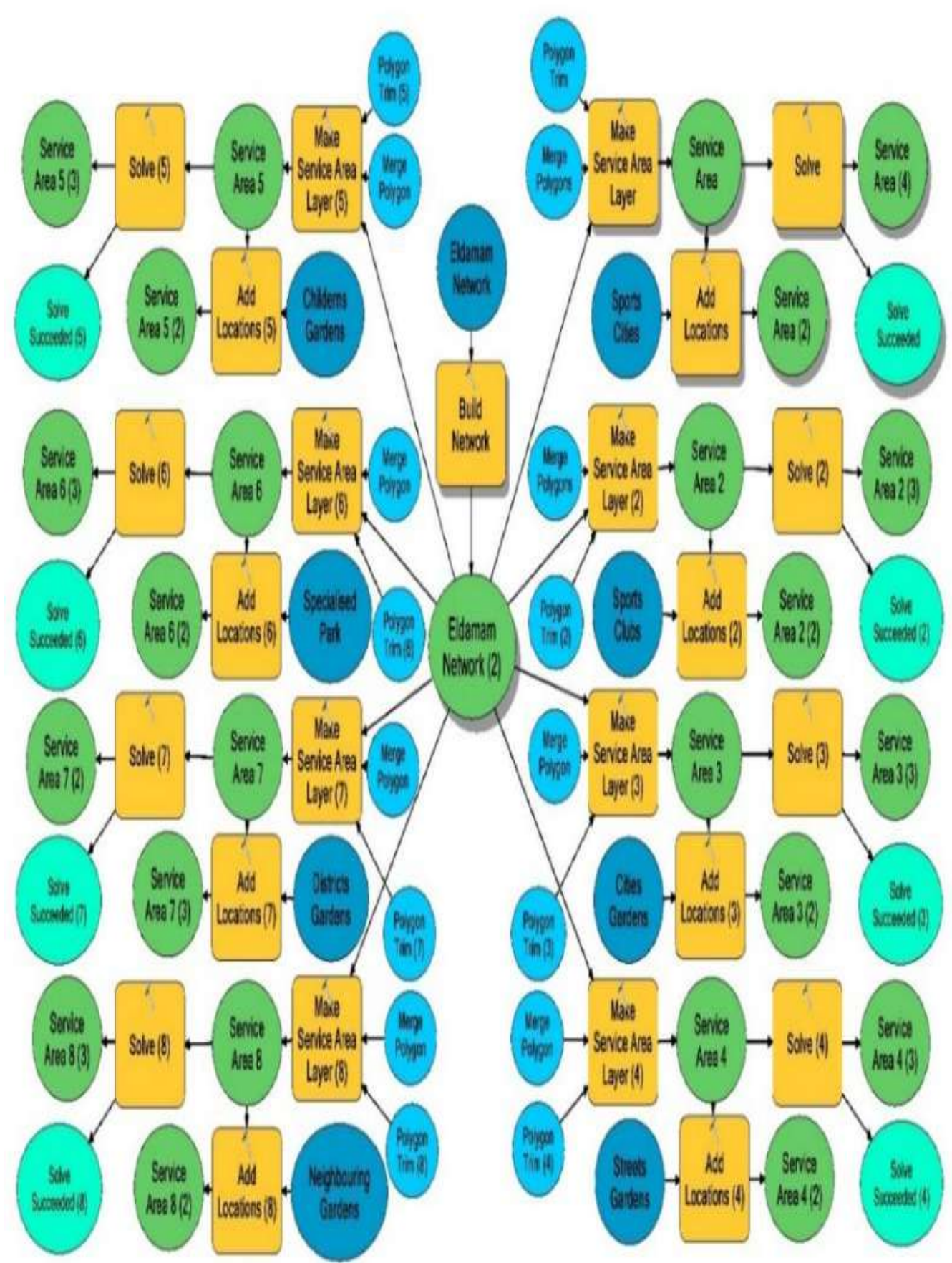

Figure 5.The structure of the Accessibility model to the green zones in Al-Dammam metropolitan area. 


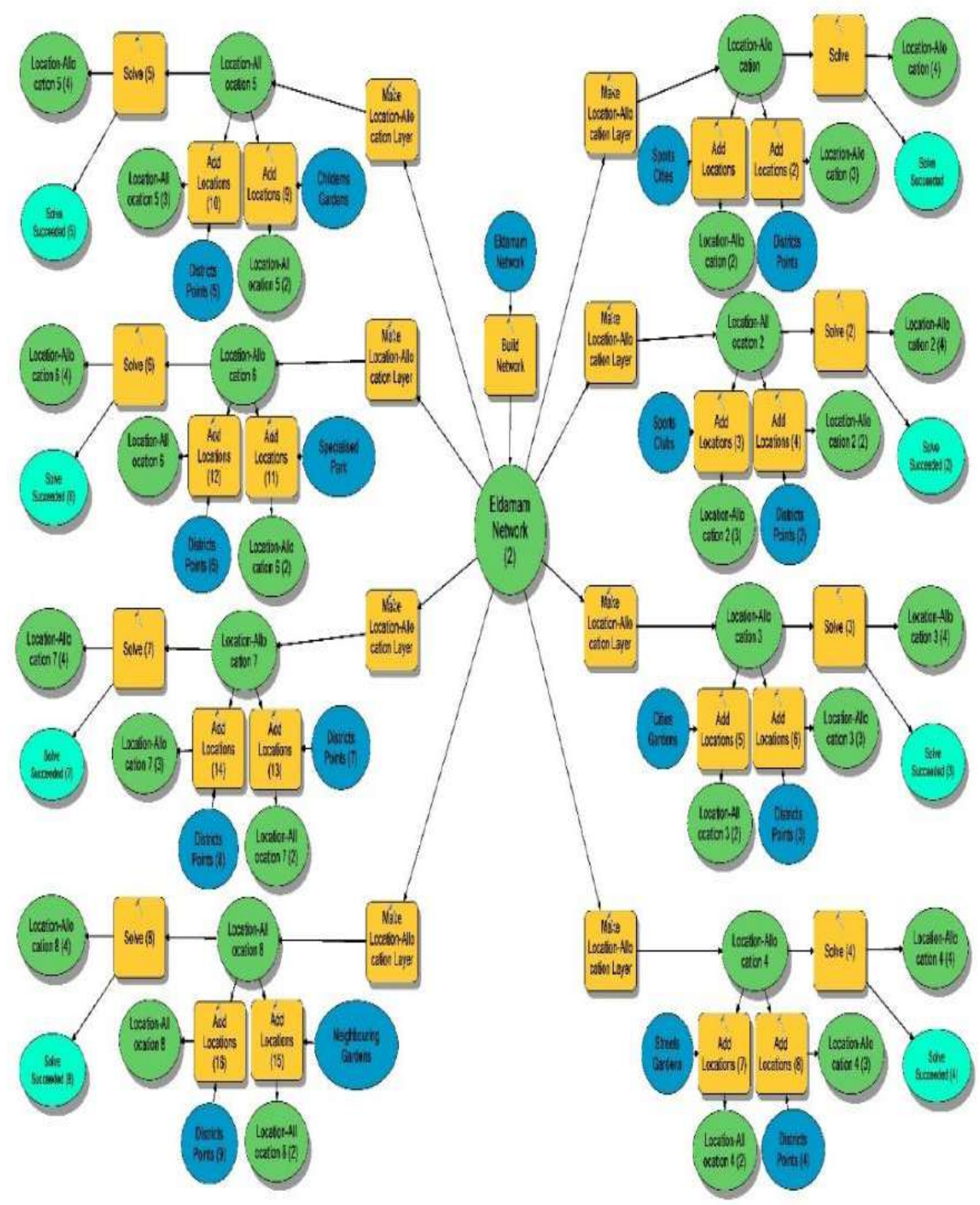

Figure 6. The structure of the Location-Allocation model of the green zones in Al-Dammam metropolitan area

The Network is then solved using the "solve" tool for obtaining results and suggesting new locations for services in all the administrative sections in Al-Dammam metropolitan area of study. 
Various GIS spatial and statistical analysis tools were used in this study such as; geographic distribution measuring tools ("standard distance" and "directional distribution"), and proximity analysis tools ("buffer"), these tools were implemented effectively to evaluate the spatial distribution pattern of the green zones in the investigated area.

This study depended on official governmental sources for data represented by the GIS unit (Issue 101, 2019) provided by the secretariat of the KSA eastern province. Twelve digital GIS layers were obtained including; the administrative borders of the cities of the KSA eastern province, the administrative division of Al-Dammam metropolitan area, the boundaries of the neighborhoods of Al-Dammam metropolitan area, and nine different green zones layers including; Children's gardens, Neighborhoods gardens, districts gardens, cities gardens, streets and squares gardens, specialized parks (corniche), playgrounds, sports clubs, and sports cities. Maps for the urban expansion were also obtained.

\section{Results and Discussion}

4.1. Geographical Distribution of the Green Zones in Al-Dammam Metropolitan Area

Many studies (Mirchandani \& Francis 1990; Marsh \& Schilling 1994; Tammy 2004; Tsou et al., 2005; Tammy \& Zvi, 2007) ensure that the spatial equilibrium is the main aim of the spatial expansion, this can be beneficial for social, urban and regional sustainability and to the rational share of the public welfare. Reaching the spatial equilibrium is an effective way for achieving the maximum social welfare, in some cases the geographic redistribution is the solution for correcting the misdistribution and achieving the fair equilibrium (Yasenovskiy \& Hodgson 2007; Puerto et al., 2009; Ma et al.,2017; Wu et al., 2018).

From the analysis of results in (table 1) and (figure 7), it was found that the total number of the green zones in Al-Dammam metropolitan area was 697 with total area of 6.88 million square meters. There were 311 "neighborhoods gardens" representing $45 \%$ of the total number of green zones with total area of about 1.1 million $\mathrm{m}^{2}$. There were 214 "specialized park" representing 31\% with total area of about 2.2 million $\mathrm{m}^{2}$. The "districts gardens" with total amount of 85 gardens represented about $12 \%$ of the total number with total area of about 976 thousand $\mathrm{m}^{2}$. The 40 “children's gardens" represented about $6 \%$ with total area of about 44 thousand $\mathrm{m}^{2}$.

Al-Dammam city's green zones were the largest in total number with 402 representing about $58 \%$ of the total green zones in Al-Dammam metropolitan area. While, Al-Khobar city 
constituted 232 green zones representing 33\%. Finally Al-Dhahran city constituted only 63 green zones representing 9\% of the total number of green zones in Al-Dammam metropolitan area. It was found that Al Shatie Al Gharbi district in Al-Dammam city constituted the largest number of green zones in the city with 140 zone representing about $34.8 \%$ of the total green zones in the city, followed by Al Hamra district by about $9.7 \%$, and then As Salam district by $4.7 \%$

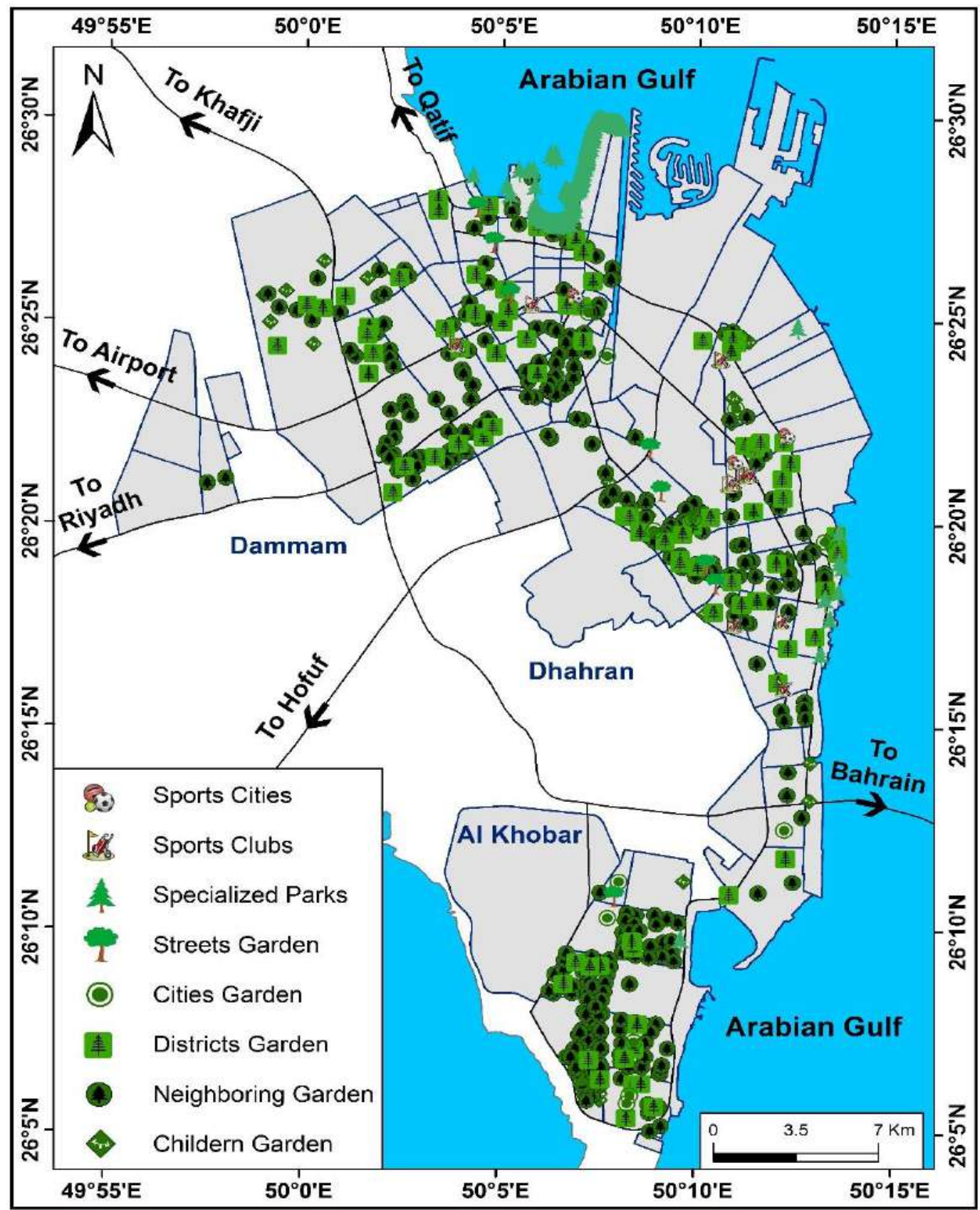

Figure 7.The geographical distribution of the green zones in Al-Dammam metropolitan area, 2019 
Regarding Al-Dhahran city, the first rank was Ad Doha Al Janubiyah district with 22 green zones representing 34.9\% of the total number of green zones in Al-Dhahran city, followed by Ad Dana Al Shamaliyah district with 28.6\% and then Ad Doha Al Shamaliyah district with 14.3\%.Concerning Al-Khobar city. Al-Morjan district constituted the largest share of the total number of the green zones in the city by 48 green zones representing $20.7 \%$ then $\mathrm{Al} \mathrm{Kawthar}$ district by $12.5 \%$ and Ash Sheraa district in the third rank by $10.3 \%$.

Table 1.The geographic distribution in terms of numbers and areas of the green zones in AlDammam metropolitan area.

\begin{tabular}{|c|c|c|c|c|c|c|c|c|}
\hline & \multicolumn{2}{|c|}{$\begin{array}{l}\text { Al-Dammam } \\
\text { city }\end{array}$} & \multicolumn{2}{|c|}{ Al-Dhahran city } & \multicolumn{2}{|c|}{ Al-Khobar city } & \multicolumn{2}{|c|}{$\begin{array}{c}\text { Al-Dammam } \\
\text { Metropolitan area }\end{array}$} \\
\hline & Number & $\begin{array}{c}(1000 \\
\left.m^{2}\right)\end{array}$ & Number & $\begin{array}{c}(1000 \\
\left.m^{2}\right)\end{array}$ & Number & $\begin{array}{c}(1000 \\
\left.m^{2}\right)\end{array}$ & Number & $\left(1000 \mathrm{~m}^{2}\right)$ \\
\hline $\begin{array}{l}\text { Neighborhood } \\
\text { gardens }\end{array}$ & 118 & 397.25 & 36 & 109.11 & 157 & 641.97 & 311 & 1148.33 \\
\hline specialized parks & 206 & 2006.22 & 0 & 0 & 8 & 289.8 & 214 & 2296.02 \\
\hline Children'sgardens & 11 & 17.07 & 11 & 8.37 & 18 & 18.65 & 40 & 44.9 \\
\hline District gardens & 44 & 502.5 & 10 & 116.13 & 31 & 357.47 & 85 & 976.1 \\
\hline $\begin{array}{l}\text { Streets and Squares } \\
\text { gardens }\end{array}$ & 4 & 148.21 & 3 & 34.33 & 1 & 53.92 & 8 & 236.46 \\
\hline city gardens & 3 & 201.97 & 2 & 156.43 & 8 & 206.93 & 13 & 565.33 \\
\hline sports city & 2 & 189.04 & 0 & 0 & 1 & 1146.22 & 3 & 1335.26 \\
\hline Sports clubs & 8 & 6.35 & 0 & 0 & 7 & 224.95 & 15 & 231.31 \\
\hline Playgrounds & 6 & 34.96 & 1 & 19.94 & 1 & 1.39 & 8 & 56.29 \\
\hline Total green zones & 402 & 3503.58 & 63 & 444.31 & 232 & 2941.3 & 697 & 6889.19 \\
\hline
\end{tabular}

The number of green zones distributed over the districts of Al-Dammam metropolitan area differed due to the different demand rates. It was noticed that the green zone type with teh largest number was the "neighborhoods gardens" serving over 67 districts representing about $49.6 \%$ of the total number of districts in Al-Dammam metropolitan area. While the least frequently established green zone type was the "sports cities" serving about 3 districts only representing about $2.2 \%$.

The geographical distribution of the green zones has been affected by the urban growth, as Al-Dammam metropolitan area witnessed an unprecedented increase and development in the urban area. During 1934 to 2018 period, the urban area increased 1281.6 times, from 34 hectares in 1,934 to 43,575 hectares in 2018 by total increase of 43,541 hectares with average annual increase of 518 hectares throughout the period. It was found that the urban mass formed before 1934 including; Ar Rabi, As Souq, Gharb Al-Dhahran, Al Thuqbah and Al- 
Khobar Al Janubiyah districts constituting the largest share of the green zones services (Fig. 8).

While, the newly founded urban mass including; Al Fursan and Al Hadabah districts in northwestern Al-Dammam metropolitan area, and Al Aqiq, Al Kawthar, Al Lo'lo', Al Amwaj and Ash Shera districts in south Al-Dammam metropolitan area suffered a serious deficiency in the green zones despite the plan to build them.

It was also noticeable that the geographical distribution of the green zones was influenced by the density of the population. The general population density in Al-Dammam metropolitan area was 33person/hectare. At the cities level; Al-Khobar city was the most densely populated in Al-Dammam metropolitan area by 35 person/hectare, followed by AlDammam city by 33 person/hectare and then Al-Dhahran city by 25 person/hectare (Figure8).

Al Thuqbah district in Al-Khobar city is characterized by the high population density reaching 659 person/hectare, followed by Al Eskan district in Al-Dammam city by 634 person/hectare. Meanwhile, Al Jawhara district in Al-Dammam city had the lowest population density, as low as 0.26 person/hectare. It was noticed that districts with population density of more than 200 person/hectare contained large numbers of green zones (i.e. there was a direct correlational relationship between the population density and the number of green zones with a strong correlation up to $98 \%$ ). 


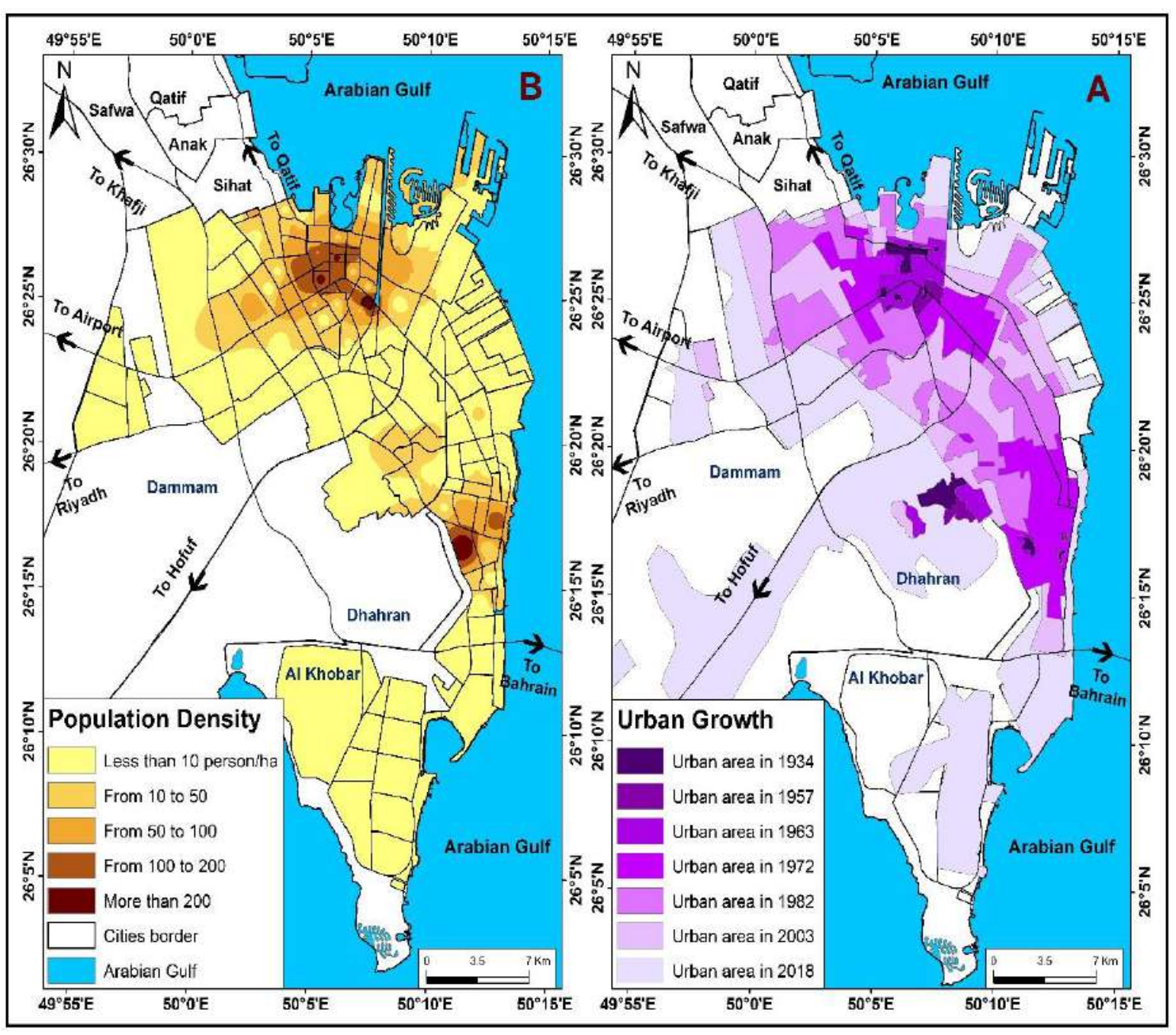

Figure 8. (A)The Urban growthand (B) the Population density in Al-Dammam metropolitan area

By analyzing the characteristics of the geographical distribution of the green zones in AlDammam metropolitan area using GIS spatial and statistical "standard deviational ellipse" analysis tools, it was found that the green zones were distributed over Al-Dammam metropolitan area in NW-SE (northwest-southeast) direction, ellipse and characterized by small size with $74.97 \%$ of the length of diameter extoending from north to south. The ellipse shape included 71 districts representing $52.59 \%$ of the total number of districts, while, the other $47.41 \%$ fell outside the ellipse (figure 9).

The geographical distribution of the types of green zones was obtained using the "standard deviational ellipse" tool and showed the distribution details as follows: for the "children's gardens", the distribution direction took NW-SE axes, the ellipsoid was characterized by large size with $61.46 \%$ of the length of diameter extending from North to 
South. The ellipse included 87 districts representing $64.44 \%$ of the total number of districts. While, $35.56 \%$ of the districts fell outside the ellipse. Regarding the services of ("neighborhoods gardens", “districts gardens", "city gardens", "streets and squares gardens", "specialized parks (cornice)", "playgrounds", "sports clubs", and "sports cities"), the distribution direction took N-S (north-south) direction and the ellipsoid was characterized by its small sizes with lengths ranging from 24.24 to $69.47 \%$ of the length of the diameter extending NW-SE (northwest-southwest).

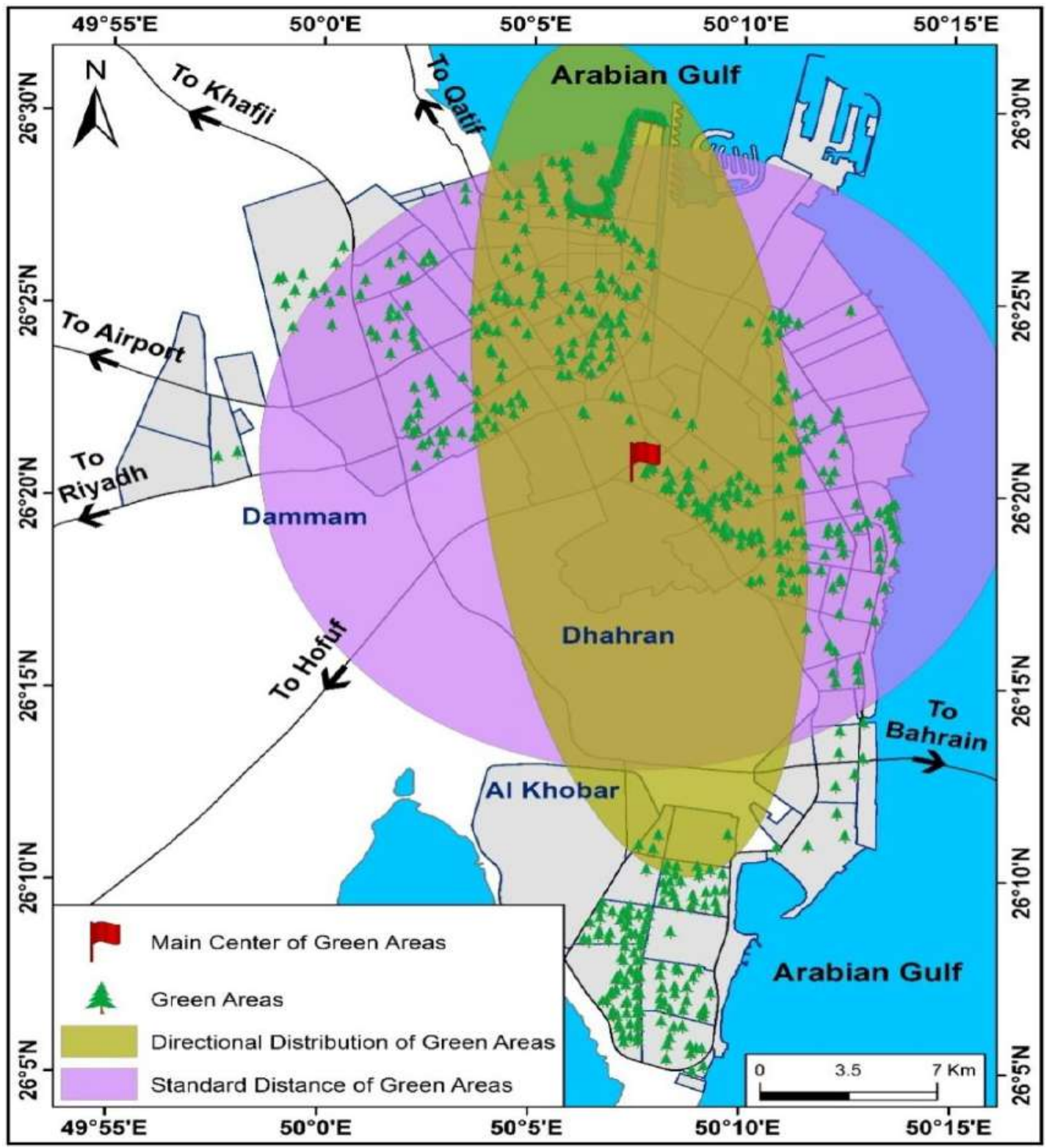

Figure 9. The distribution direction, standard deviational distance, and the mean center for the green zones in Al-Dammam metropolitan area, 2019 
From the analysis of the "mean center" results, it was found that the mean geographic center of the ("children's gardens", "neighborhoods gardens", "district gardens", "city garden", and "specialized parks") services lie in Gharb Al-Dhahran district; while, for the "streets and squares gardens", the geographic center lied in the Hagr district; for the "playgrounds", it lied in AbdallahFouad district; for the "sports clubs", it lied in the sports city district; and for the "sports cities", it lied in Al Hussam district.

From the analysis of the "average nearest neighbor distance" results, it was noticable that the spatial distribution of the green zones had a "clustered pattern" with value of $(0.45)$ and zvalue of (-27.65) which was lower than the critical value of z-parameter. For the types of green zones of ("children's gardens", "neighborhoods gardens", “districts gardens", "specialized parks", and "sports clubs"), the pattern of distribution was "clustered patterns" with values ranging from ( 0.28 to 0.49$)$ and Z-values ranging from -6.63 to 19.93 .

While, the green zones types of ("cities gardens", "streets and squares gardens", and "playgrounds") were found to have "random patterns" of distribution with values ranging from (1.02 to 1.28$)$ and z-values from (0.11 to 1.52$)$. The distribution pattern of the "sports city" type of green zones was found to be a "dispersed pattern" with value of (3.51) and zvalue of (8.33) (figure 10).

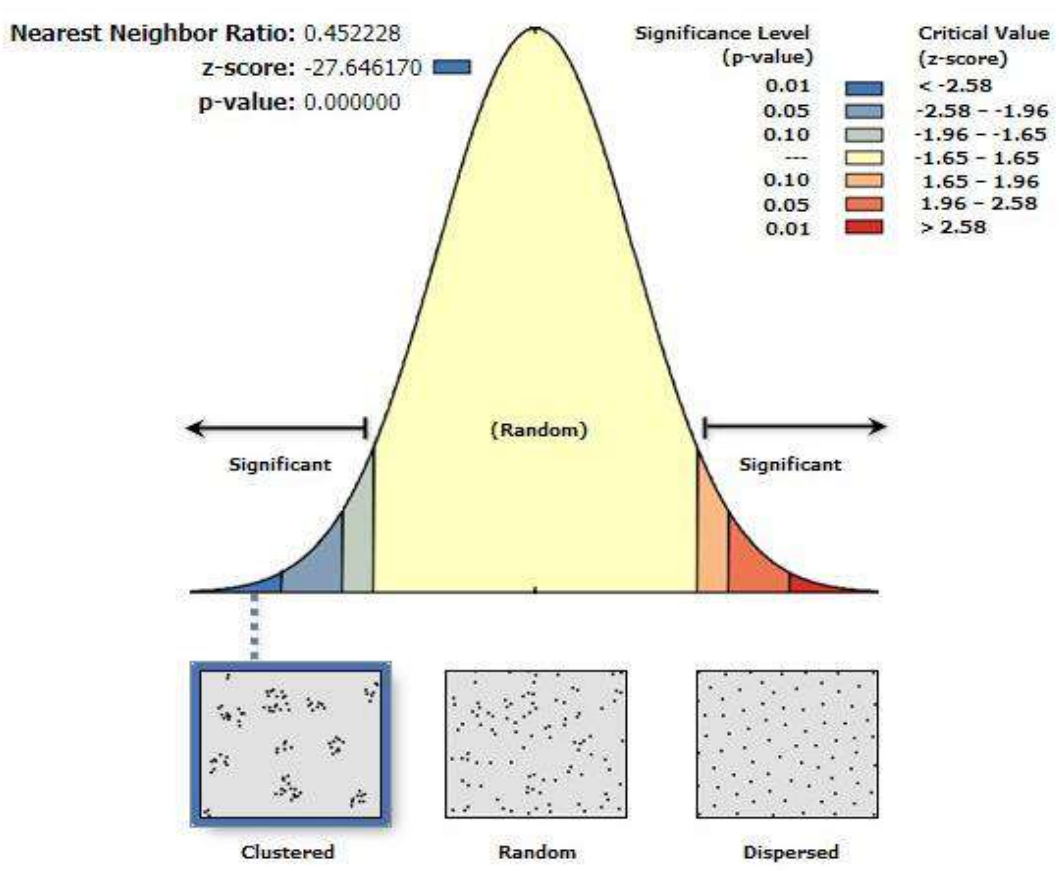

Figure 10.The Nearest Neighbor Analysis for the green zones in Al-Dammam metropolitan area, 2019 
4.2. Evaluation of the Efficiency of the Green Zones in Al-Dammam Metropolitan Area

4.2.1. Basics and Criteria of the Urban Planning (Quantitatively and Spatially) for the Assessment of the Green Zones Efficiency

Determining the efficiency and adequacy of the spatial distribution of the green zones is a very important element of the contemporary urban planning (Castella et al., 2005), which gained enormous benefits from the modern techniques, especially, the GIS spatial and statistical analysis tools. This comes for ensuring the ease of accessibility to the green zones through selecting (allocating) the optimal locations and through the fair distribution of these zones (Ohta et al., 2007; Howerton, 2006; Zhu et al., 2005). The optimal traffic rates an area of focus to the planners, geographers and decision-makers; this reflects the importance of the development of the spatial analysis in GIS. Spatial analysis is one of the most important functions of the GIS because the results of this analysisare used as the basis of the decisions making and new maps generation (Cody \& Heather 2017; Johannes \& Hubert 2017).

This study is based on the standards set by the KSA Ministry of Municipal and Rural Affairs for evaluating the efficiency and planning the current and future needs of green zones in Al-Dammam metropolitan area. Therefore, the results of study were introduced to the decision-makers (table 2).

Table 2. The 2019 planning standards (quantitative and spatial) of green zones in Al-

Dammam metropolitan area

\begin{tabular}{|c|c|c|c|c|c|}
\hline & \multirow{2}{*}{$\begin{array}{c}\text { Service } \\
\text { population rates } \\
\text { (person) }\end{array}$} & \multicolumn{2}{|c|}{$\begin{array}{l}\text { Per capita green zones } \\
\text { rates }\left(\mathrm{m}^{2} / \text { person }\right)\end{array}$} & \multicolumn{2}{|c|}{$\begin{array}{l}\text { The spatial buffer of the } \\
\text { services (m) }\end{array}$} \\
\hline & & Lower & higher & $\begin{array}{l}\text { lower } \\
\text { limit }\end{array}$ & Higher limit \\
\hline sports city & $\begin{array}{l}500000- \\
1000000\end{array}$ & 0.18 & 0.2 & $\begin{array}{l}5000 \\
\text { meter }\end{array}$ & 10000 meter \\
\hline sports clubs & $100000-250000$ & 0.4 & 0.8 & 250 meter & 500 meter \\
\hline playgrounds & $50000-100000$ & 0.7 & 1 & 800 meter & 1200 meter \\
\hline specialized parks & +100000 & 0.6 & 0.8 & $\begin{array}{l}2500 \\
\text { meter }\end{array}$ & 5000 meter \\
\hline $\begin{array}{l}\text { streets and squares } \\
\text { gardens }\end{array}$ & $50000-150000$ & 0.45 & 0.7 & 500 meter & 1000 meter \\
\hline city gardens & +40000 & 0.3 & 0.4 & $\begin{array}{l}2000 \\
\text { meter }\end{array}$ & 5000 meter \\
\hline district gardens & $15000-25000$ & 0.4 & 0.5 & 400 meter & 800 meter \\
\hline neighborhood gardens & $3000-5000$ & 0.9 & 1.2 & 100 meter & 250 meter \\
\hline children's gardens & $1500-4000$ & 0.22 & 0.33 & 50 meter & 275 meter \\
\hline total & & 4.15 & 5.93 & & \\
\hline
\end{tabular}


Reviewing the current standings of the per capita rates of the green zones in AlDammam metropolitan area (figure11)and (table 3), it was found that the rate was $3.52 \mathrm{~m}^{2} /$ person. This rate was lower than the standard rate of $5.9 \mathrm{~m}^{2} /$ person determined by the Ministry of Municipal and Rural Affairs of KSA. At the cities level; it was found that the per capita rates of the green zones in Al-Dammam city was $3.15 \mathrm{~m}^{2} /$ person. While, for AlKhobar city, it was $4.21 \mathrm{~m}^{2} /$ person, and for Al-Dhahran city, it was $3.03 \mathrm{~m}^{2} /$ person. It was clear that in Al-Dammam and Al-Dhahran cities, the rates were obviously lower than the standard rate, while in Al-Khobar city, it was fairly compatible with the planning standard rate.

Table 3.The 2019 per capita rates of green zones in Al-Dammam metropolitan area

\begin{tabular}{|c|c|c|c|c|}
\hline Green zones & $\begin{array}{l}\text { Al-Dammam } \\
\text { city }\end{array}$ & $\begin{array}{l}\text { Al-Dhahran } \\
\text { city }\end{array}$ & $\begin{array}{l}\text { Al-Khobar } \\
\text { city }\end{array}$ & $\begin{array}{c}\text { Al-Dammam } \\
\text { Metropolitan area }\end{array}$ \\
\hline $\begin{array}{l}\text { "neighborhood gardens" } \\
\left(\mathrm{m}^{2} / \text { person }\right)\end{array}$ & 0.36 & 0.74 & 0.92 & 0.59 \\
\hline $\begin{array}{l}\text { "specialized parks" } \\
\left(\mathrm{m}^{2} / \text { person }\right)\end{array}$ & 1.80 & 0.00 & 0.41 & 1.17 \\
\hline $\begin{array}{l}\text { "children's gardens" } \\
\left(\mathrm{m}^{2} / \text { person }\right)\end{array}$ & 0.02 & 0.06 & 0.03 & 0.02 \\
\hline $\begin{array}{l}\text { "district gardens" } \\
\left(\mathrm{m}^{2} / \text { person }\right)\end{array}$ & 0.45 & 0.79 & 0.51 & 0.50 \\
\hline $\begin{array}{l}\text { "streets and Squares } \\
\left.\text { gardens" ( } \mathrm{m}^{2} / \text { person }\right)\end{array}$ & 0.13 & 0.23 & 0.08 & 0.12 \\
\hline "city gardens" ( $\mathrm{m}^{2} /$ person $)$ & 0.18 & 1.07 & 0.30 & 0.29 \\
\hline "sports city" (m²/person) & 0.17 & 0.00 & 1.64 & 0.68 \\
\hline "sports clubs" ( $\mathrm{m}^{2} /$ person $)$ & 0.01 & 0.00 & 0.32 & 0.12 \\
\hline "playgrounds" ( $\mathrm{m}^{2} /$ person) & 0.03 & 0.14 & 0.00 & 0.03 \\
\hline Total $\left(\mathrm{m}^{2} /\right.$ person $)$ & 3.15 & 3.03 & 4.21 & 3.52 \\
\hline
\end{tabular}

At the districts level, there were four main categories of the per capita rates of green zones. The first category was for the districts with per capita rates less than $2.5 \mathrm{~m}^{2} /$ person. This included 40 districts representing $29.63 \%$ of the total districts in Al-Dammam metropolitan area, inhabited by 1,116,127 inhabitants representing about $57 \%$ of the total population. Al Jalawiyah, AzZuhur, Al Anoud, ArRawdah, Hagr, Al Muraikabat, Al Mazruiyah, Ohud, Al Wahah, and Al Badee districts were the most important districts included in the first category. The second category comprised of districts with per capita ranging from 2.5 to $5 \mathrm{~m}^{2}$ /person, including 17 districts representing $12.6 \%$ with 226,139 inhabitants representing $11.5 \%$ of the total population. 


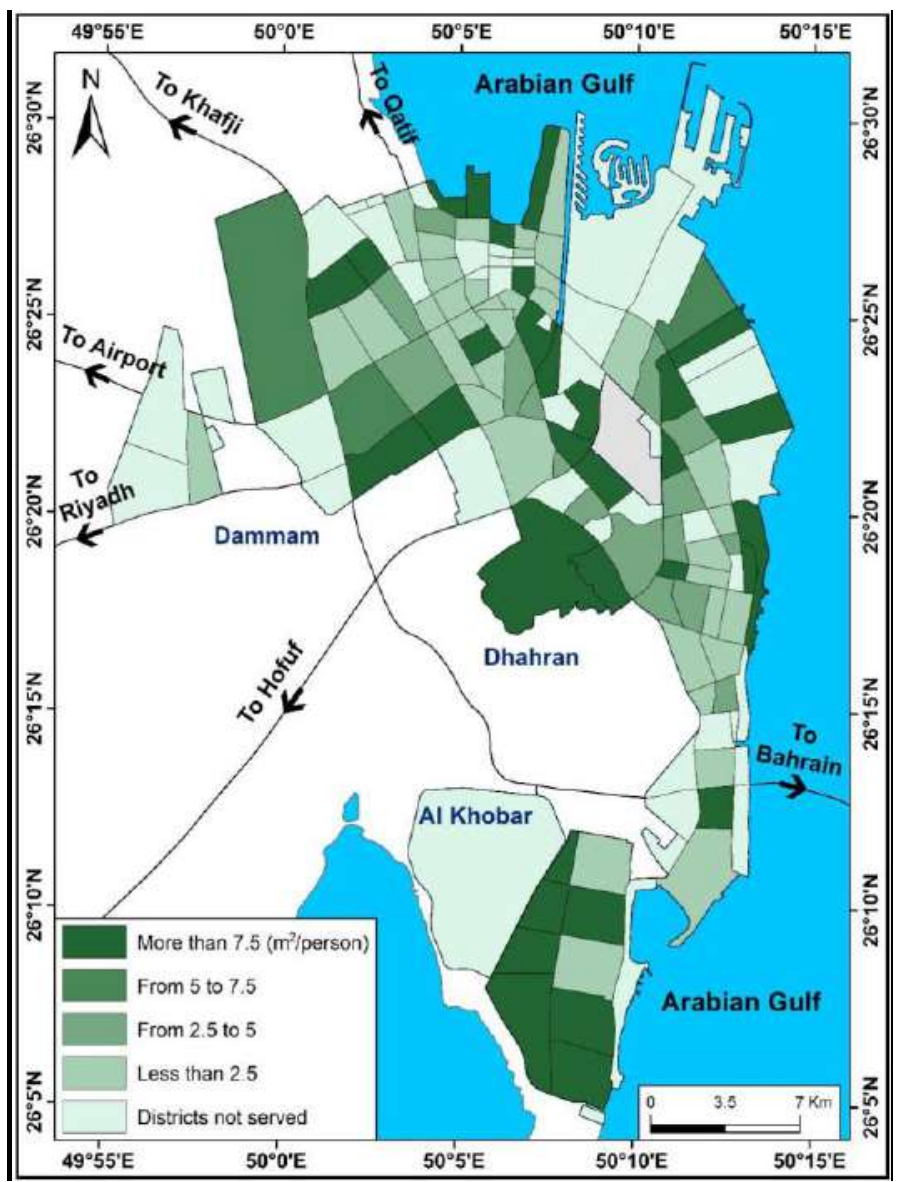

Figure 11. The per capita rates of total green zones in Al-Dammam metropolitan area, 2019

The most important districts of the second category included: ArRakah Ash Shamaliyah, An Nuzhah, Al Hussam, Al Firdaws, Tuhamah, Al Aziziyah, Ad Dabab, Al Faisaliyah, Ad Dana Al Janubiyah, and Ad Doha Al Shamaliyah.

The third category comprised of districts with per capita rates ranging from 5 to 7.5 $\mathrm{m}^{2} /$ person, this category was represented by 3 districts (An Nawras, King Fahd suburb, and Al Manar) representing $2.22 \%$ of the total districts and containing 20,573 inhabitants representing $1.1 \%$ of the total population in Al-Dammam metropolitan area.

The fourth category comprisedof districts with per capita green zones rates of more than $7.5 \mathrm{~m}^{2} /$ person.It comprised of 30 districts representing about $22.22 \%$ of the total districts in Al-Dammam metropolitan area, inhabited by 163,427 inhabitants representing about $8.3 \%$ of the total population. The districts of Al Fanar, ArRayyan, An Nur, Al Hamra, As Sadafa, Al Shatie Al Gharbi, Qasr Al Khalij, As Salam, As Safa, and An Nada were regarded the most important districts included in the fourth category. From the previous statistical analysis, it was found that there were existing green zones in 90 districts representing about $66.6 \%$ of the 
districts of Al-Dammam metropolitan area and inhabited by 1,526,266 inhabitants. While, the other 45 districts with 432,478 inhabitants did not own any green zones.

By applying the GIS "buffer" technique to evaluate the effectiveness of the green zones types; it was found that; using $250 \mathrm{~m}$ buffer for the "neighborhoods gardens", about $47 \%$ of the districts fell outside the 800m effective buffer of the "districts gardens" (figure12), 87\% of the districts fell outside the $275 \mathrm{~m}$ effective buffer of the "children's gardens", $44 \%$ of the districts fell outside the 5,000m effective buffer of the "specialized parks" (figure13), $81 \%$ of the districts were outside the 1,000m effective buffer of the "streets and squares gardens", $81 \%$ of the districts were outside the $500 \mathrm{~m}$ effective buffer of the "cities gardens" (figure 14 ), $84 \%$ of the districts were outside the $500 \mathrm{~m}$ effective buffer of the "sports clubs", and $24 \%$ of the districts were outside the 10,000 m effective buffer of the "sports cities" (figure15).

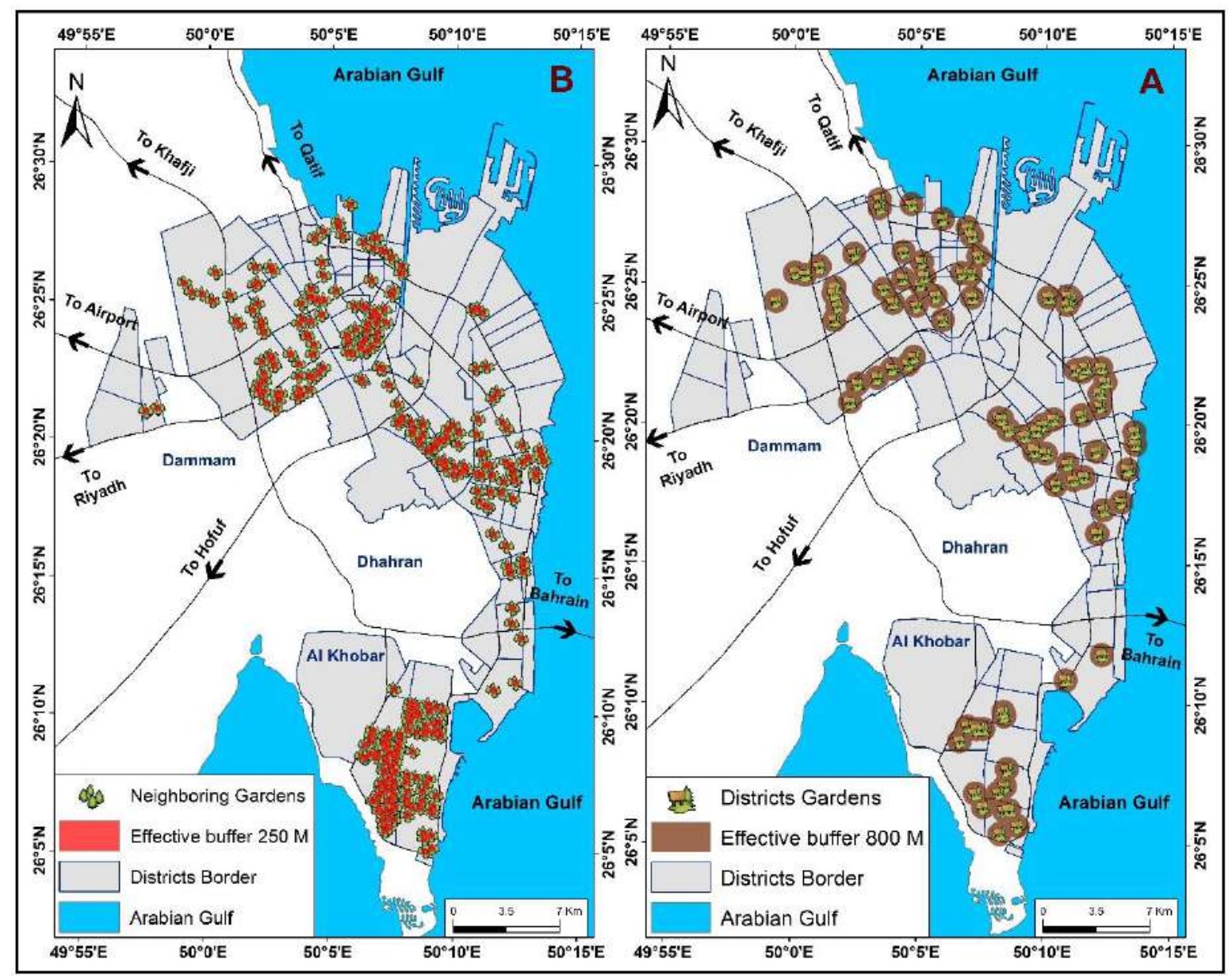

Figure 12.The effective buffers of green zones of (A) districts gardens, and (B) neighborhoods gardens in Al-Dammam metropolitan area, 2019. 


\subsubsection{The Accessibility Analysis for Evaluating the Efficiency of the Green Zones}

Green zones represent the main lung for hiking and spending the leisure time. It indicates a better standard of living of the population as it protects the natural and environmental resources and enhances the environmental conditions. Therefore, it became a necessity the existence of green zones and open areas connected by an integrated network for fulfilling the various needs of population. In fact, applying the accessibility and the location-allocation models represent a planning enhancement and assessment processes depending on mathematical modeling in GIS (Cromley \& McLafferty, 2002; Rais \& Viana2010; Cho 1998).

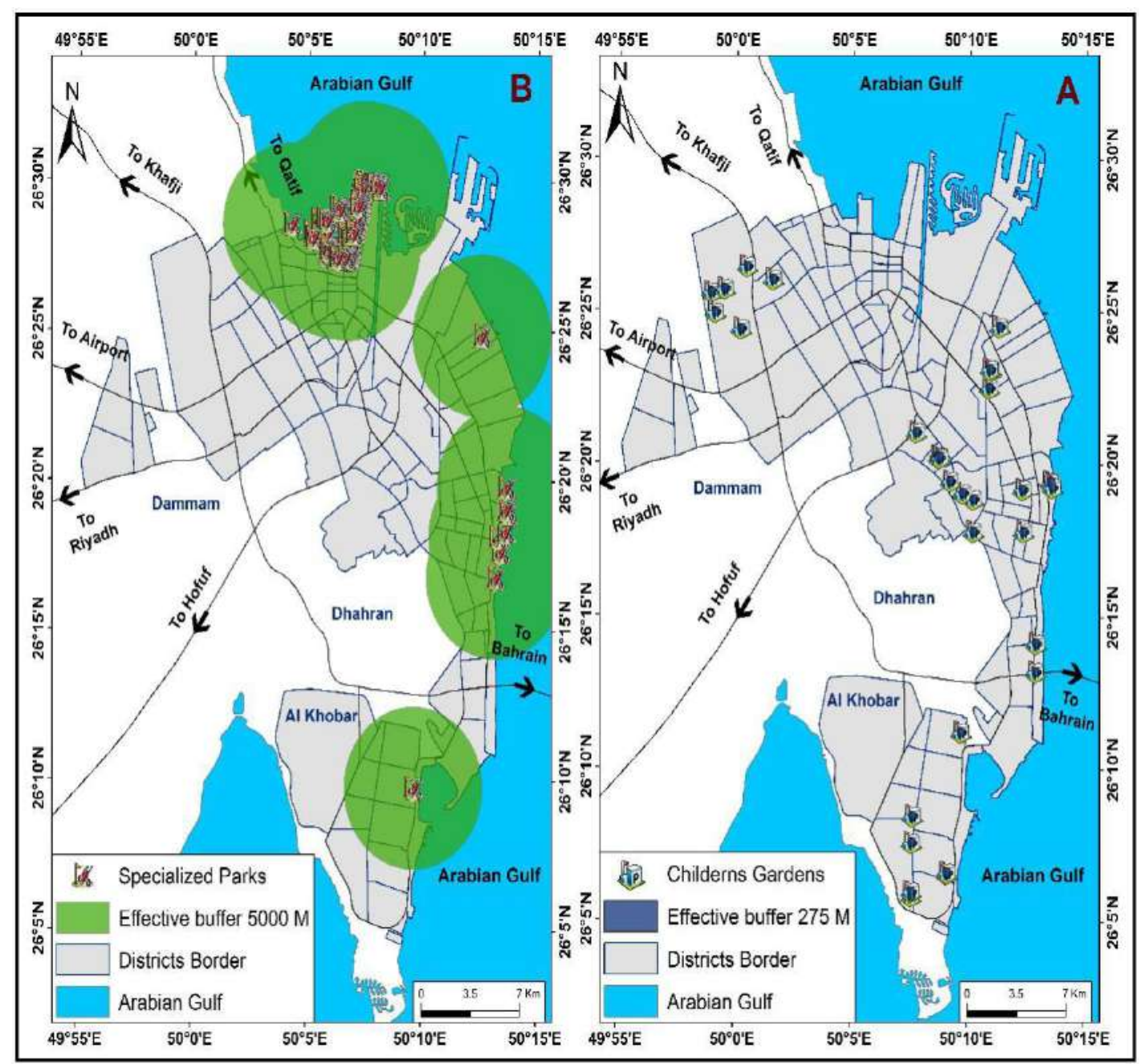

Figure 13.The effective buffers of green zones of (A) children's gardens, and (B) specialized parks in Al-Dammam metropolitan area (2019) 
Ashraf Abdelkarim/ GEOSI Vol 5 No 1 (2020) 1-46

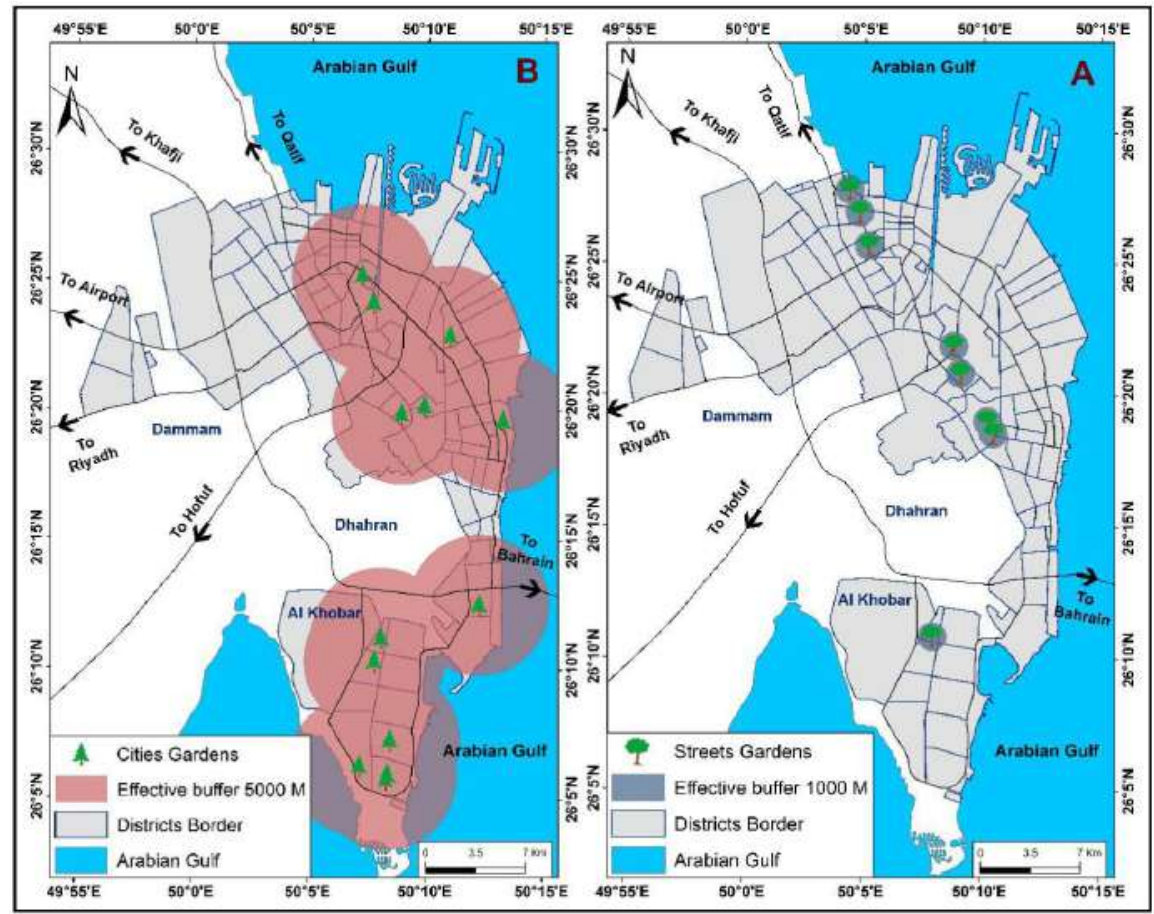

Figure 14.The effective buffers of green zones of (A) streets gardens, and (B) cities gardens in Al-Dammam metropolitan area ( 2019)

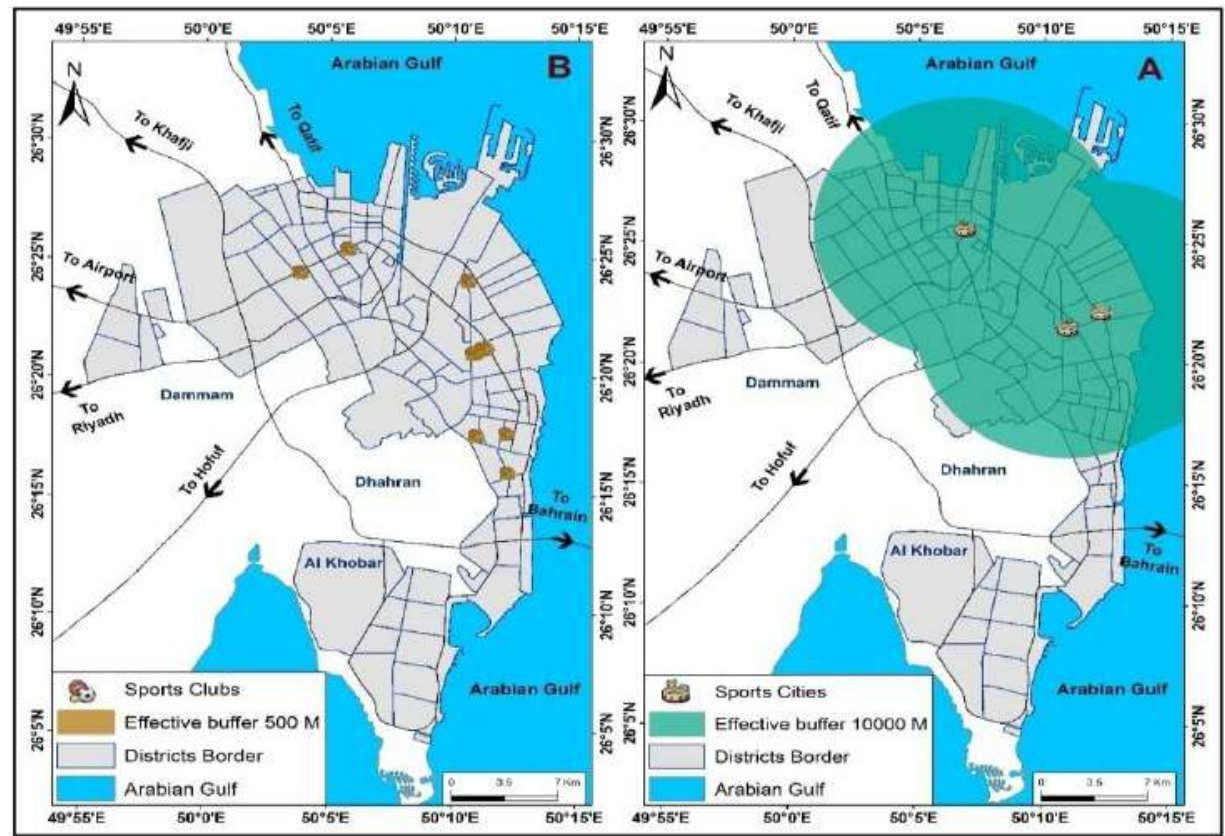

Figure 15.The effective buffers of green zones of (A) sports cities, and (B) Sports clubs in AlDammam metropolitan area (2019).

The analysis results of the accessibility to the green zones in Al-Dammam metropolitan area within time intervals of 5, 10, and 15 minutes revealed that: for the "districts gardens" 
service; the coverage area within 5 minutes included 130 districts representing $96.3 \%$ of the total 135 districts of Al-Dammam metropolitan area. While, within 10 and 15 minutes, the coverage included all the 135 districts. For the "neighborhoods gardens" service; the coverage within 5 minutes included all the 135 districts (figure16).

For the "children's gardens" service; the coverage area within 5 minutes included 103 districts representing $76.3 \%$ of the total 135 districts of Al-Dammam metropolitan area.While, within 10 and 15 minutes, the coverage included all the 135 districts. For the "specialized parks" service; the coverage area within 5 minutes included 103 districts representing $76.3 \%$ of the total 135 districts of Al-Dammam metropolitan area. While, within 10 minutes, the coverage included 129 districts (95.6\%), and within 15 minutes, the coverage included 134 districts (99.3\%) (figure17).

For the "streets and squares gardens" service; the coverage area within 5 minutes included 110 districts representing $81.5 \%$ of the total 135 districts of Al-Dammam metropolitan area. While, within 10 minutes, the coverage included 131 districts (97\%), and within 15 minutesincluded all the 135 districts. For the "cities gardens" service; the coverage area within 5 minutes included 113 districts representing $83.7 \%$ of the total 135 districts of Al-Dammam metropolitan area, while, within 10 minutes, included 130 districts (96.3\%), and within 15 minutes included all the 135 districts (figure 18).

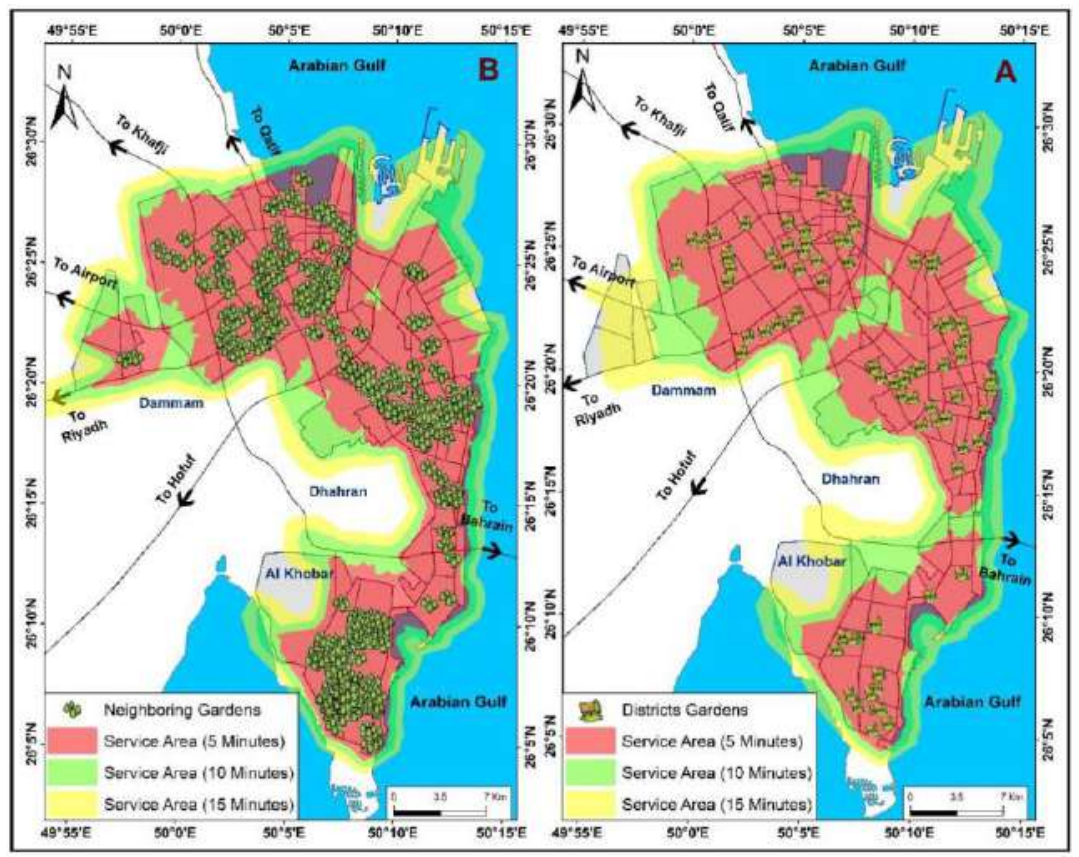

Figure 16. Access on foot to the green zones in Al-Dammam metropolitan area; (A) districts gardens, and (B) neighborhoods gardens depending on the GIS accessibility to service area technique 


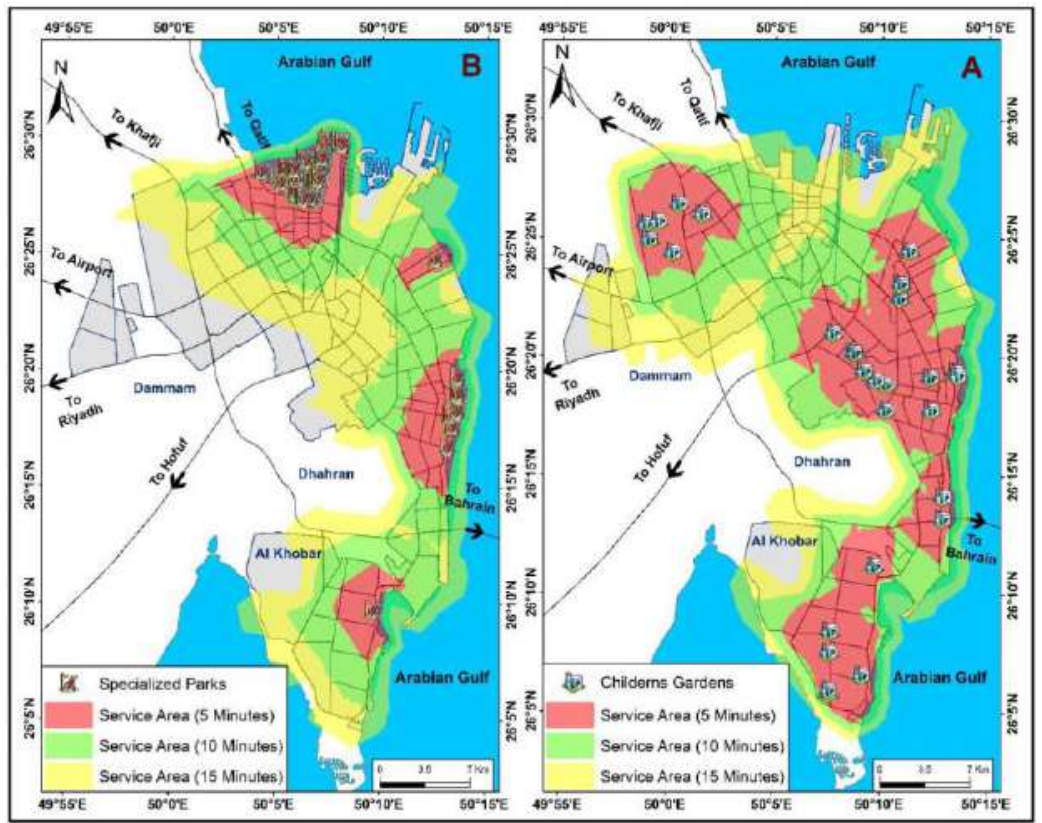

Figure 17. Access on foot to the green zones in Al-Dammam metropolitan area; (A) children's gardens, and (B) specialized gardens depending on the GIS accessibility to service area technique

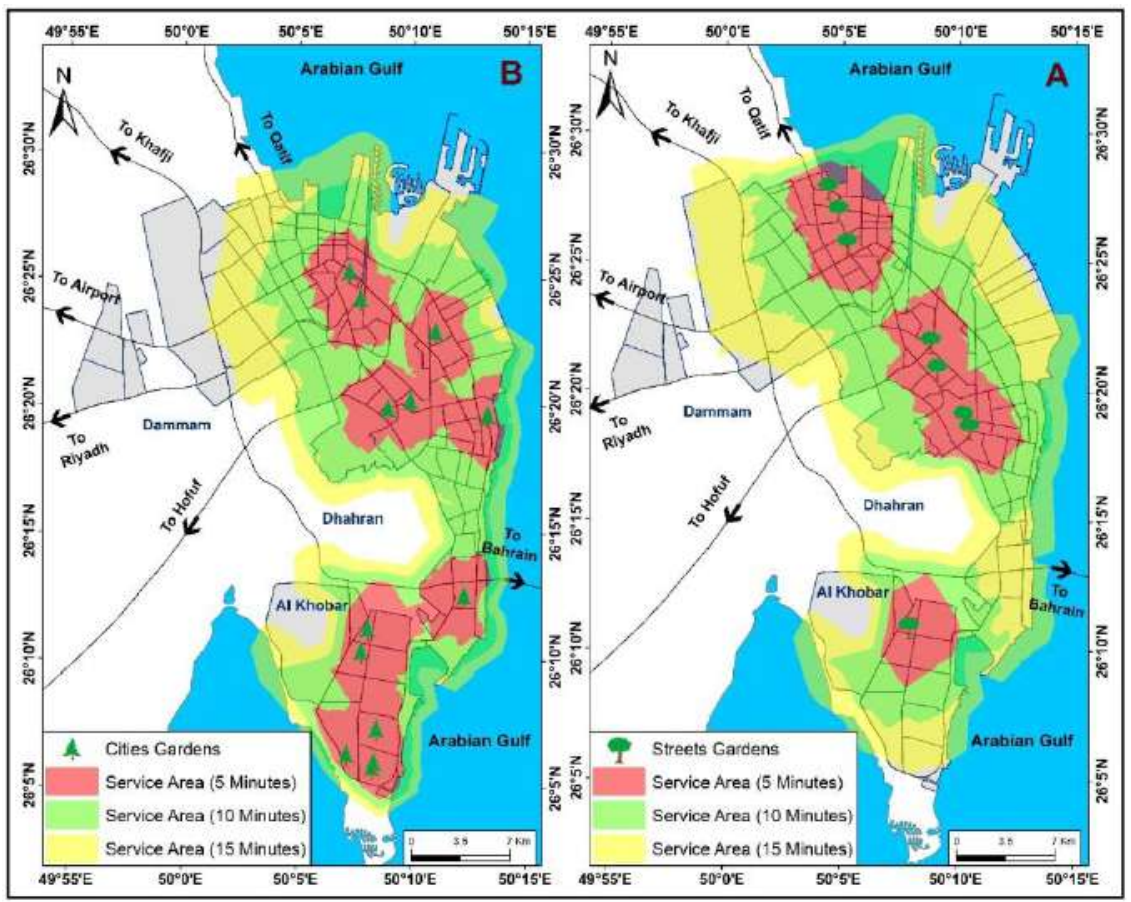

Figure 18. Access on foot to the green zones in Al-Dammam metropolitan area; (A) streets gardens, and (B) cities gardens depending on the GIS accessibility to service area technique

For the "sports city" service; the coverage area within 5 minutes included 83 districts representing $61.5 \%$ of the total 135 districts of Al-Dammam metropolitan area. While, within 10 minutes, the coverage included 110 districts (81.5\%), and within 15 minutes included 122 
districts (90.4\%). For the "sports clubs" service; the coverage area within 5 minutes included 110 districts representing $81.5 \%$ of the total 135 districts of Al-Dammam metropolitan area. While, within 10 minutes, the coverage included 128 districts (94.8\%), and within 15 minutesincluded 133 districts (98.5\%) (figure19).

\subsection{Combined Coverage of Green Areas for Neighborhoods in Dammam Metropolitan Area}

At this stage, Raster's Sum was compiled to map the green areas resulting from the analysis of the networks of the 9 types: neighboring garden, specialized park, children's gardens, cities gardens, neighborhood park, street and squares park, sports city, sports clubs, and playgrounds within the information system environment. The Spatial Analyst Tool was selected from the Toolbox, from which the algorithm was selected on the Map Algebra and then on the Raster Calculator(Figure 20). Dammam in terms of their access to green areas were as follows:

\subsubsection{Neighborhoods with High Green Areas (Coverage Ranges from 85-100\%)}

The results of the analysis of the different accessibility analysis in Dammam metropolitan area revealed that there were sixty-four districts representing about $47.4 \%$ of the total number of Dammam metropolitan areas.

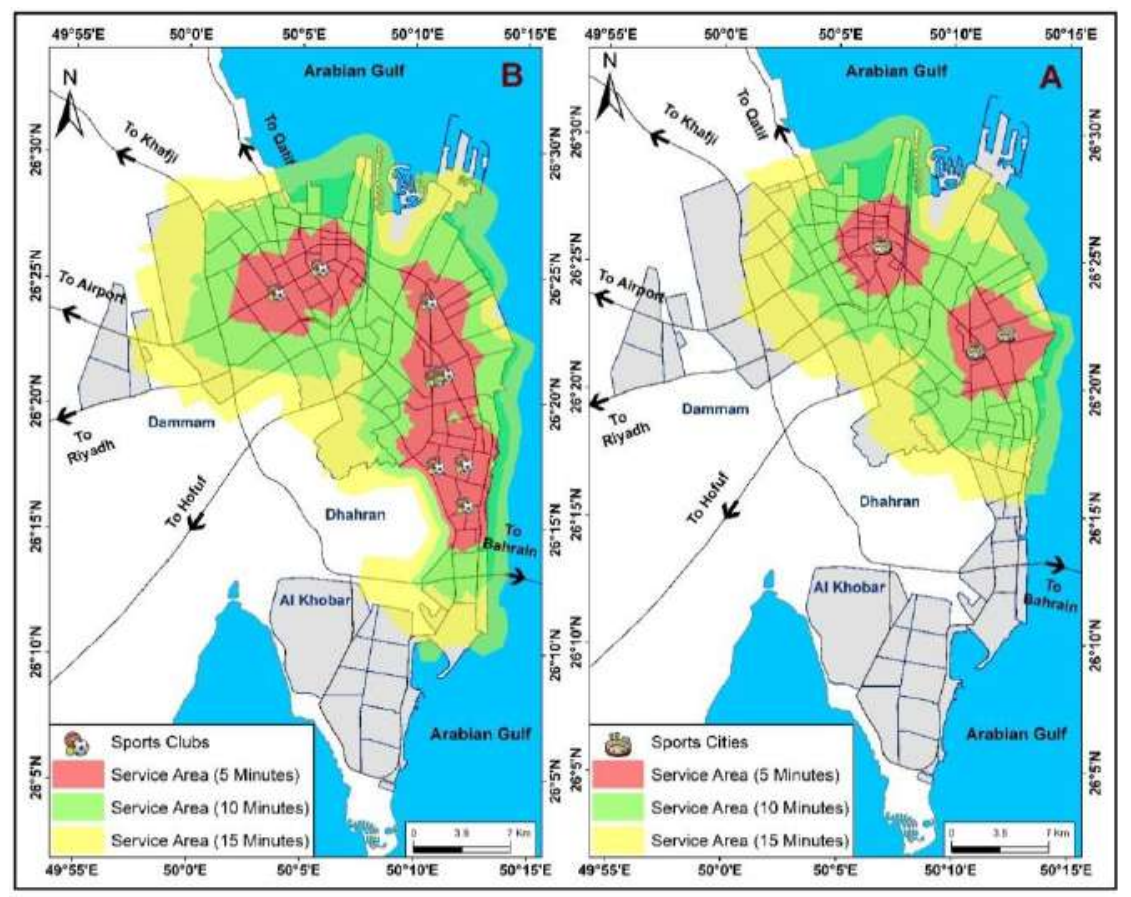

Figure 19. Access on foot to the green zones in Al-Dammam metropolitan area; (A) sports cities, and (B) sports clubs depending on the GIS accessibility to service area technique 
The level of green areas was high and was highly spatially suitable for living for easy access to green areas with the least distance and the fastest time. 1,325,218 inhabitants constituting $67.7 \%$ of the total population of Dammam Metropolitan Area, with an area of about 171.7 square kilometers representing $28.8 \%$ of the total area of Dammam Metropolitan Area. These districts were concentrated in the center and north of Dammam Metropolitan Area, which benefited from its unique geographical location and its organic tissue with clear boundaries.

Where the kernel were included,most of the neighborhoods in this category were very high in occupancy and construction and were characterized by high population density. These factors combined made this category enjoy the best coverage of the green areas of the Dammam Metropolitan Area

\subsection{2 . Neighborhoods with Medium Green Areas: (65-85\% Coverage)}

This category included forty-eight neighborhoods representing about $35.5 \%$ of the total neighborhoods of Dammam metropolitan. The population of these neighborhoods was 492,146 inhabitants, which constituted $25.1 \%$ of the total population of Dammam metropolitan area. These neighborhoods were located around the former high-class north and south, and these neighborhoods were characterized by a medium population density, and an appropriate road network. 
Ashraf Abdelkarim/ GEOSI Vol 5 No 1 (2020) 1-46

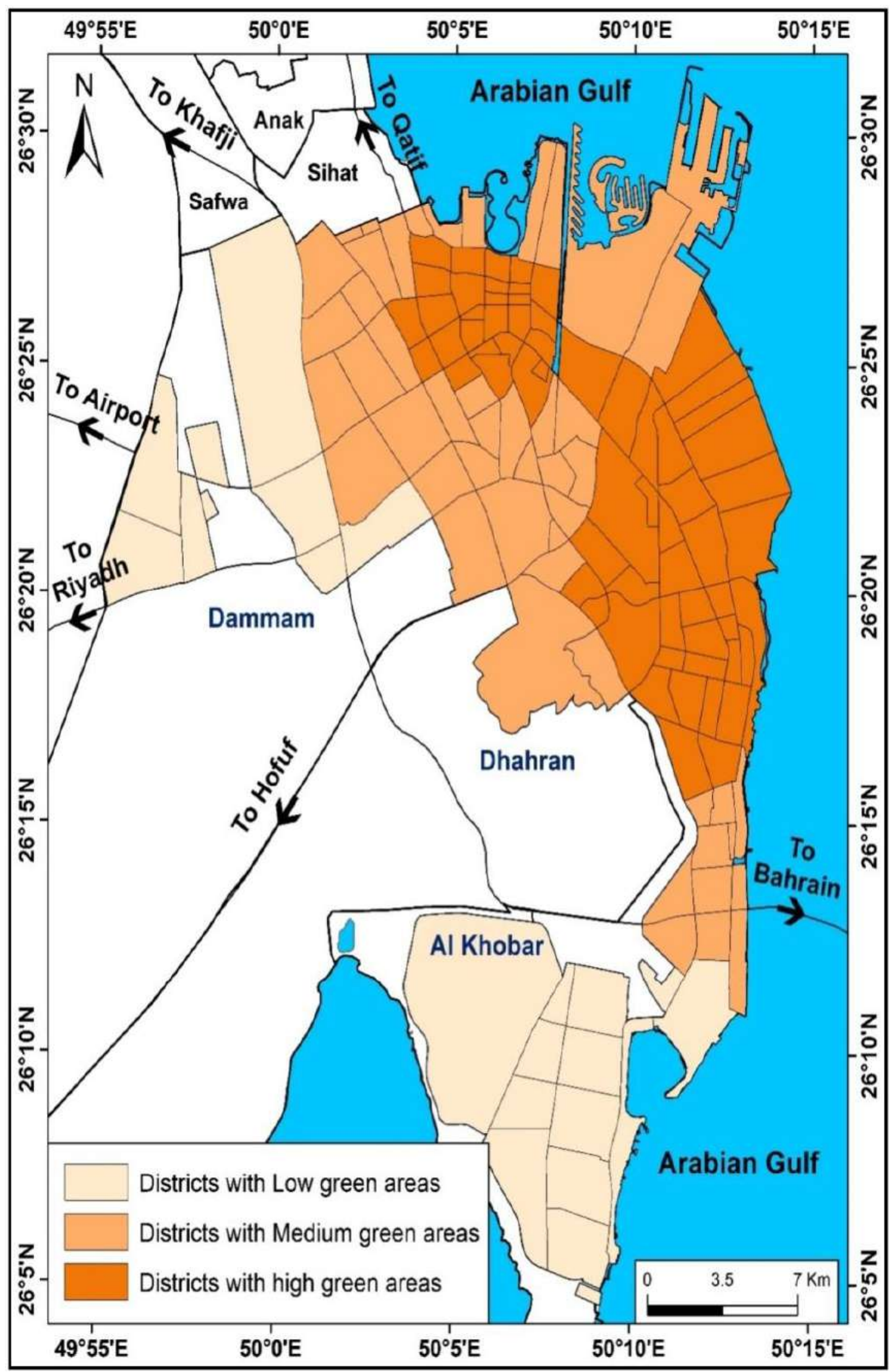

Figure 20.Classification of green areas coverage based on arithmetic addition (Raster's Sum) 


\subsection{3 .Neighborhoods with Low Green Areas: (Covered Less than 65\%)}

This category included twenty-three neighborhoods representing about $17 \%$ of the total neighborhoods of Dammam metropolitan area, inhabited by 141,387 inhabitants, which constituted $7.2 \%$ of the total population of Dammam metropolis, living on an area of about 205.3 square kilometers representing $34.4 \%$ of the total area of Dammam metropolitan area. The reasons behind the low rate of access to the green areas of these neighborhoods was due to its distance from the old nucleus of Dammam metropolis, which were completed by many services, facilities and infrastructure, and the poor road network in addition to the distance from the facade of the Nile Corniche, which wasattracted by many green areas services. There was a reflection of many of the factors that influenced the map of the green areas in urban area, which came at the head of the distribution and density of the population, the age and modernity of the neighborhoods, the area and location of the neighborhoods, modern urban extensions, transportation and transportation, private sector participation, and retail planning of secretariats.

4.4. The location-Allocation Model for Determining the Current Needs and for Planning the Future of the Green Zones

The location-allocation model was regarded a very powerful tool for planning the public utilities to find the best locations for facilities to ensure the maximum benefit and the fair sharing of services. Its applications was previously limited because of data unavailability. However, currently there are existing "land information systems" in many cities providing the required data and parameters for the location-allocation model. Achieving the spatial equilibrium of the green zones in Al-Dammam metropolitan area through allocating locations for the green zones services is an effective planning approach for maximizing the social welfare and improving the spatial planning of the green zones. The GIS-based locationallocation model allows generating planning alternatives either by suggesting an effective service or by improving an existing one.

In the present study, the "maximum coverage" location-allocation model was applied with response time of no more than 10 minutes. The results were as follows: within response time of 10 minutes, the "sports city" service covered 105 districts representing $77.8 \%$ of the total 135 districts in Al-Dammam metropolitan area. The covered (serviced) districts by the 
"sports city" service were found to be located in the central and northern parts of AlDammam metropolitan area. To ensure all the districts are covered by this service, two "sports cities" are suggested to be allocated, one in the north western part of Al-Dammam metropolitan area and the other one in the southern part. Within response time of 10 minutes, the "sports clubs" service covered 123 districts representing $91.1 \%$ of the total 135 districts. The covered districts by the "sports clubs" service were found to be located in the central and northern parts of Al-Dammam metropolitan area. To ensure all the districts are covered by this service, two "sports clubs" are suggested to be allocated, one in the north western part of the area and the other one in the southern part (figure 21).

Within 10 minutes response time, the "streets and squares gardens" service covered 128 districts representing $94.8 \%$, these districts were found to be covering all Al-Dammam metropolitan area except the northwestern and southern parts of the area. To cover all the districts by this service, two "streets and squares gardens" are suggested to be allocated in the missing parts of the area. Within 10 minutes response time, the "cities gardens" service covered 127 districts representing $94.1 \%$ of the total 135 districts of Al-Dammam metropolitan area; these districts were found to be covering all area except of the northwestern part of the area. Consequently, one "city garden" is suggested to be allocated in the northwestern part of the area (figure22).

Within 10 minutes response time; the "children's gardens" service covered 134 out of the 135 districts representing 99.3\%, the missing district was found to be located in the northwestern part of the area. Consequently, one "children's garden" is suggested to be allocated in this part of the area. Within 10 minutes response time; the "specialized parks" service covered 125 districts representing $92.6 \%$ of the total number of districts in the study area; the covered districts were found to be located in the northern and eastern parts of the investigated area. Hence, one "specialized park" is suggested to be allocated in the northwestern part of the area as this part is not currently covered by this service. It was also found that, all the 135 districts of Al-Dammam metropolitan area were covered by the services of "districts gardens" and "neighborhoods gardens" within the defined 10 minutes response time (figure 23). 
Ashraf Abdelkarim/ GEOSI Vol 5 No 1 (2020) 1-46

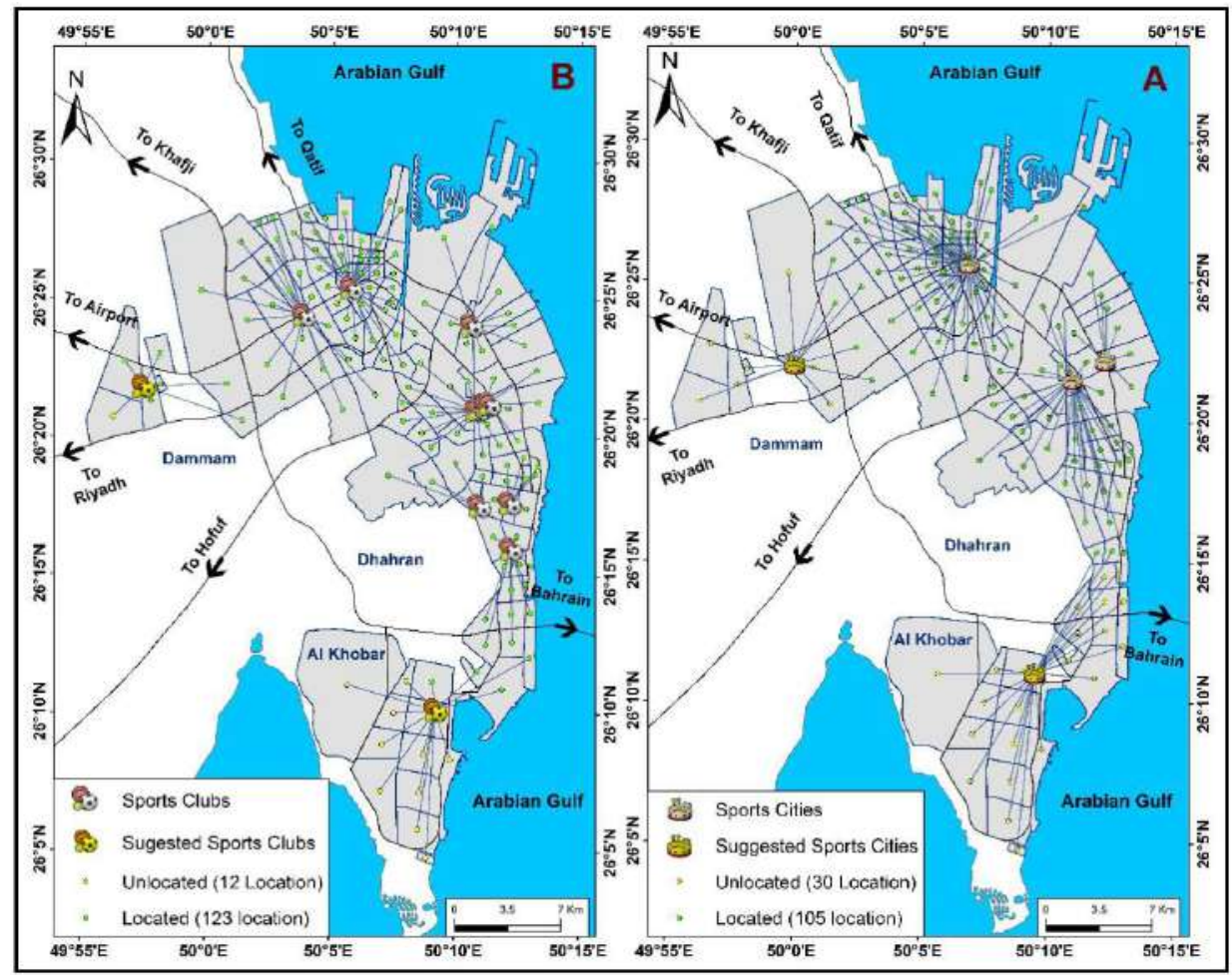

Figure 21.The suggested locations in Al-Dammam metropolitan area; (A) sports cities, and (B) sports clubs based on the GIS location-allocation modeling

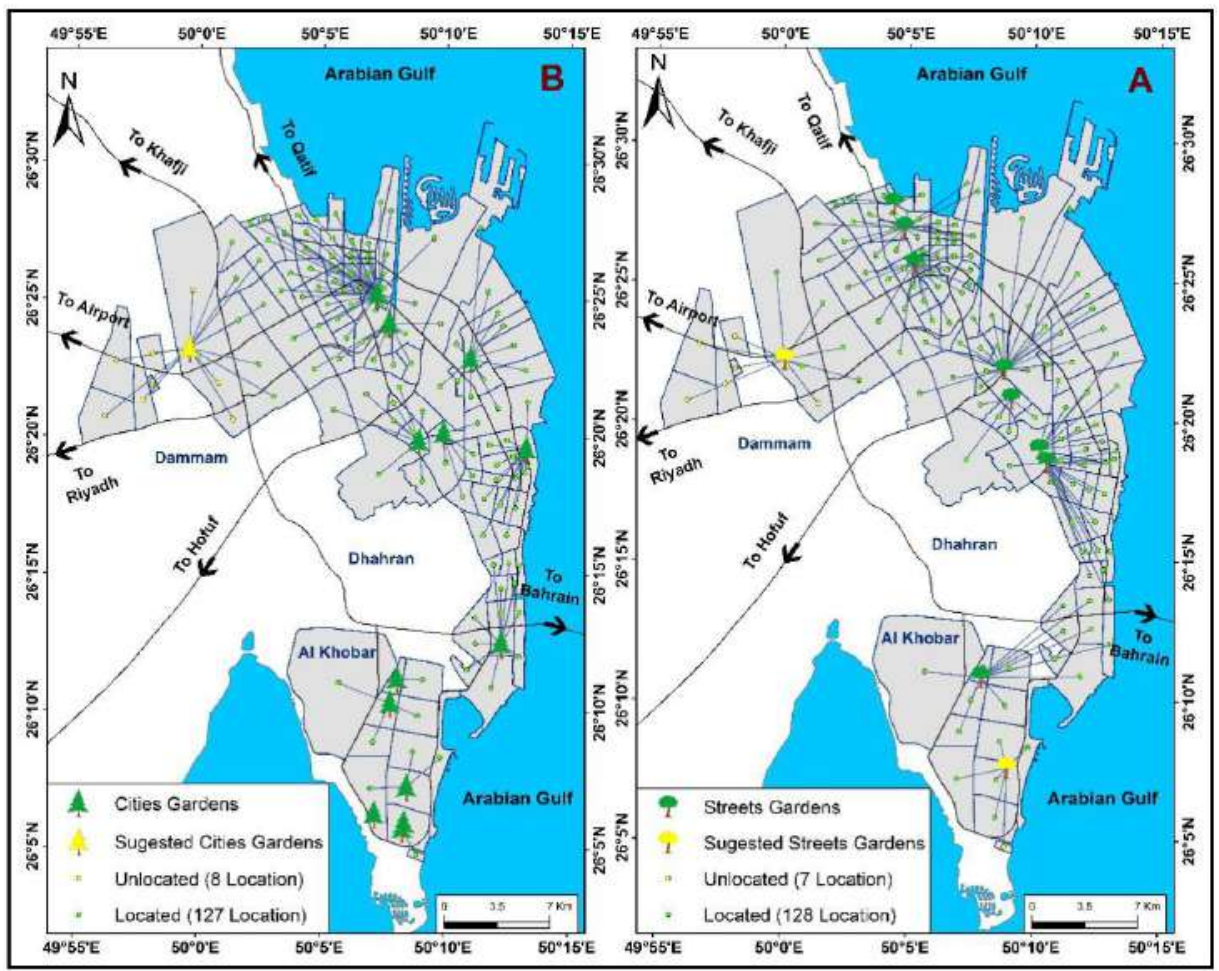

Figure 22.The suggested locations in Al-Dammam metropolitan area; (A) streets gardens, and (B) cities gardens based on the GIS location-allocation modeling 


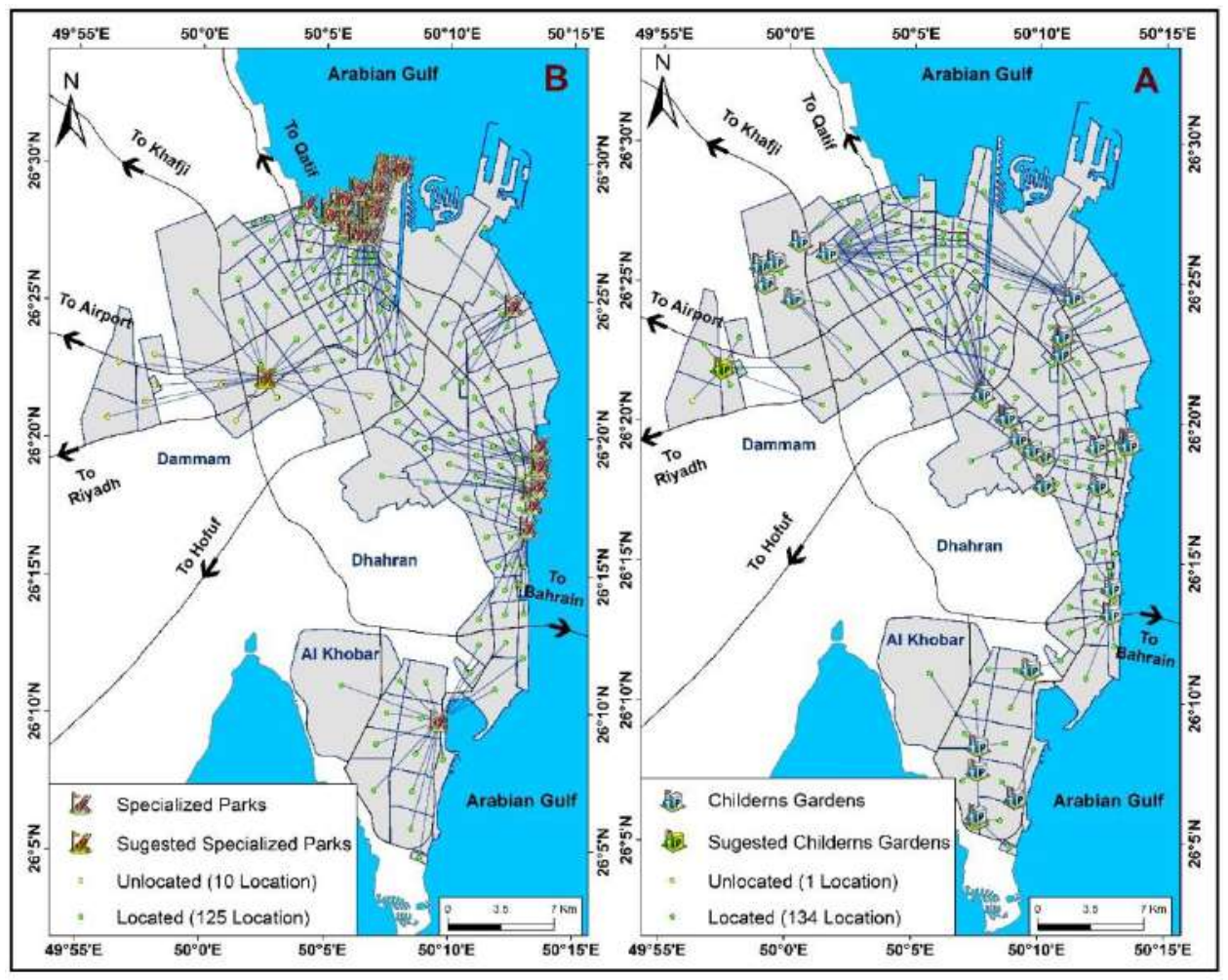

Figure 23.The suggested locations in Al-Dammam metropolitan area; (A) children's gardens, and (B) specialized gardens based on the GIS location-allocation modeling

\section{Recommendations}

The recreational services provided by the green zones are regarded the main development elements in Al-Dammam metropolitan area. Any deficiency either in the type, quantity or spatial distribution is a strong limitation of the sustainable urban development. The current increasing population rates, the urban expansion, and the increasing regional, functional, and administrative roles of Al-Dammam metropolitan area puts extra lodes on the urban planning of the area. In addition, the lower per capita rates of green zones in AlDammam metropolitan area and the deficiency of coverage and accessibility to all the services of green zones during the defined 5, 10, and 15 minutes time to the service. This gives a negative effect and poses a great challenge for the green sustainability and the recreational activities.

This study recommends the redistribution of the green zones regularly based on the density and needs of population in all the districts of Al-Dammam metropolitan area. This requires fulfilling the current deficiencies of green zones that are estimated in this study by nine green zones services, i.e. two "sports cities", two "sports clubs", two "streets and 
squares gardens", one "district garden", one "children's garden", and one "specialized park". It is also recommended that the area of the green zones should be increased to raise the per capita rates to meet the planning standards of the Ministry of Municipal and Rural affairs of KSA.

Attention should be paid to the unused $40 \mathrm{~km}$ long waterfronts through the establishment of some recreational facilities such as gardens, parks, and high class restaurants. These waterfronts can be also better used through building terraces, planting them, providing seating places and ensuring regular cleaning and maintenance. The recreational areas should be provided with other services and facilities to form the so-called "combined services areas" in the form of hierarchy. These combined services areas should be planned as planning units divided according to the density of population and the demand on the services. This will raise the efficiency, decrease the supply cost and make it easy for the public to deal with these services.

This study recommends the need to increase the availability of toilets in the gardens and permanent maintenance of them, with the need for the presence of cleanersto work continuously to maintain children's toys in the gardens, with increased signage and placement in each corner of the gardens, with the need to install waste baskets commensurated with the nature of the areas green gardens. Some the industrial uses have become within the urban cluster; therefore, there is a need to turn them into green areas to improve the urban environment of the present.

This study also recommends activating the social partnership between both the public and private sectors through exchanging opinions and views for improving the efficiency of the green zones services. The governmental support to the private sector is also preferred for improving the green zones and facilitating regular continuous maintenance of its services and providing the most up to date services with modern techniques as the needs of the population in Al-Dammam metropolitan area.

Finally, it is also strongly recommended taking into consideration the factors of ease of accessibility to public services together with the urban planning standards and the GIS spatial and statistical analysis techniques while planning and/or evaluating the green zones in cities (i.e. the methodology of this study is recommended to be applied on similar green zones in other cities). 


\section{Conclusion}

The population growth, urban expansion, and the rapid growth of civilization attributed to the petroleum discovery in Al-Dammam metropolitan area yielded a negative effect on the urban environment in the area. The lower per capita rates of green zones that differs from one district to another makes it a necessity to reconsider the planning and distribution of the green zones, especially with the current spatial expansion and the increasing land prices that led to the existence of some other types of land-use in areas previously planned to be allocated for green zones. Therefore, increasing the area of the green zones became a necessity for achieving the sustainable environmental equilibrium in Al-Dammam metropolitan area.

This study combined the GIS accessibility and location-allocation models with the urban planning standards of the Ministry of Municipal and Rural affairs of KSA for improving the spatial planning of the green zones in Al-Dammam metropolitan area. Using the Accessibility models only allows the evaluation of the current services provided by the green zones, but, it is not capable of suggesting new locations for services or reallocation of existing services. Therefore, there is a need to integrate accessibility analysis into the location-allocation model.

The results of applying this unique integrated technique revealed the lower per capita rates of the green zones in Al-Dammam metropolitan area by $3.52 \mathrm{~m}^{2} /$ person than the defined standard of $5.9 \mathrm{~m}^{2} /$ person of the Ministry of Municipal and Rural affairs of KSA. At the cities scale; in Al Dammam city, the per capita rate was $3.15 \mathrm{~m}^{2} /$ person. While, in Al Khobar city the rate was $4.21 \mathrm{~m}^{2} /$ person, and in $\mathrm{Al}$ Dhahran city the rate was $3.03 \mathrm{~m}^{2} /$ person. Therefore, the per capita rates of the green zones in Al Dammam and Al Dhahran cities was sharply lower than the planning rates, while, the rate in Al Khobar city was fairly compatible with the standard planning rates.

There are 90 districts representing $66.7 \%$ of the total districts in Al-Dammam metropolitan area containing green zones, while the other 45 districts that represent $33.3 \%$ contained no green zones. There is deficiency in the coverage of the services to all the districts within time of $(5,10$, and 15$)$ minutes. The services coverage range from $75 \%$ to $98 \%$ of the districts. The "specialized parks" and "children's gardens" services came in the lowest rank by covering only $75 \%$ of the total districts. While, the "sports clubs" service came in the first rank by covering $89 \%$ of the districts. Al-Dammam metropolitan area suffers deficiency in fulfilling the needs of its population of green zones services. The deficiency 
was determined in this study by nine services to be established including two "sports cities", two "sports clubs", two "streets and squares gardens", one "district garden", one "children's garden" and one "specialized park"). This study provides a spatial decision support system that enables the decision makers to better evaluate and plan the green zones services in a scientific, balanced, reasonable and clear manner for seeking the sustainable development.

\section{Conflict of Interest}

The authors declare that there is no conflict of interest with any financial, personal, or other relationships with other people or organizations related to the material discussed in the article.

\section{References}

Abdulkader, M. (2018). "Using GIS for Defining Public Services Catchment Area at Jeddah City."European Journal of Scientific Research.149 (3): 279-288. ISSN 1450216X/1450-202X.

Abdulkader, M.(2018). "Using GIS for Determining Variations in Health Access in Jeddah City, Saudi Arabia." ISPRS Int. J. Geo-Inf. 7 (7): 254. https://doi.org/10.3390/ijgi7070254.

Angela, L. (2014). “There's a meadow outside my workplace': A phenomenological exploration of aesthetics and green roofs in Chicago and Toronto." Landscape and Urban Planning. 126: 94-106. https://doi.org/10.1016/j.landurbplan.2014.01.008.

Bahram, S., Mohammad, S., Biswajeet, P., and Mostafa, G. (2018). "Optimized LocationAllocation of Earthquake Relief Centers Using PSO and ACO, Complemented by GIS, Clustering, and TOPSIS."ISPRS Int. J. Geo-Inf, 7 (8): 292. https://doi.org/10.3390/ijgi7080292.

Bolund, P., and Hunhammar, S. (1999). "Ecosystem services in urban areas." Ecological Economics.29 (2): 293-301. https://doi.org/10.1016/S0921-8009(99)00013-0.

Castella, J., Manh, P., Kam S., Villano, L., and Tronche, N. (2005).“Analysis of Village Accessibility and Its Impact on Land Use Dynamics in a Mountainous Province Of Northern Vietnam.”Applied Geography. $25 \quad$ (4): 308-326. https://doi.org/10.1016/j.apgeog.2005.07.003.

Cho, C. (1998). "An equity-efficiency trade-off model for the optimum location of medical care facilities."Socio-Econ.Plan. Sci. 32 (2): 99-112. https://doi.org/10.1016/S00380121(97)00007-4. 
Cody, B., and Heather, A. (2017).“Green urban landscapes and school-level academic performance."Landscape and Urban Planning. 160: 16-77. https://doi.org/10.1016/j.landurbplan.2016.11.011.

Coombes, E., Jones, P., and Hillsdon, M. (2010). "The relationship of physical activity and overweight tot objectively measured green space accessibility and use." Social Science \& Medicine. 70 (6): 816-822. https://doi.org/10.1016/j.socscimed.2009.11.020.

Cromley, E., and McLafferty, S. (2002). "GIS and Public Health; the Guilford Press: New York, NY, USA.

Dai, D. (2011). "Racial/Ethnic and Socioeconomic Disparities in Urban Green Space Accessibility: Where to Intervene?." Landscape and Urban Planning. 102 (4): 234244.https://doi.org/10.1016/j.landurbplan.2011.05.002.

Dallimer, M., Rouquette, R., Skinner, J., Armsworth, R., Maltby, M., Warren, H., and Kevin, J. (2012). "Contrasting patterns in species richness of birds, butterflies and plants along riparian corridors in an urban landscape."Diversityand Distributions. 18 (8): 742-753. https://doi.org/10.1111/j.1472-4642.2012.00891.x.

Daniel, R., Paul, P., and Rachel, O. (2017)."Impacts of population density and wealth on the quantity and structure of urban green space in tropical Southeast Asia."Landscape and Urban Planning. 157: 553-560. https://doi.org/10.1016/j.landurbplan.2016.09.005.

Daniels, D., and Kirkpatrick, B. (2006). "Comparing the characteristics of front and back domestic gardens in Hobart, Tasmania, Australia."Landscape and Urban Planning. 87 (4): 344-352.https://doi.org/10.1016/j.landurbplan.2005.11.004.

Daskin, M., and Dean, L. (2004). "Location of health care facilities. Handbook of OR/MS in Health Care: AHandbook of Methods and Applications." Evanston, IL. 43-76, http://www.econ.upf.edu/ ramalhin/Referencias/Daskin_2004.pdf

De Vries, S., Verheij, A., Groenewegen, P., and Spreeuwenberg, P. (2003). "Natural environments-Healthy environments?An exploratory analysis of the relationship between green space and health." Environ. Plan A. 35 (10):1717-1731, https://doi.org/10.1068/a35111.

Department for Environment Food and Rural Affairs.(2019). “A Green Future: Our 25 Year Plan to Improve theEnvironment; HM Government: London, UK, 2018."Int. J.Environ. Res. Public Health, 2019, 16, 337313 of 15.

Dinand, E., and Sjerp, V. (2017). "Nearby green space and human health: Evaluating accessibility metrics." Landscape and Urban Planning. 157: 214-220. https://doi.org/10.1016/j.landurbplan.2016.06.008.

Dong, W., Gregory, B., and Yan, L. (2015)."The physical and non-physical factors that influence perceived access to urban parks."Landscape and Urban Planning. 133: 53-66. https://doi.org/10.1016/j.landurbplan.2014.09.007. 
Dongkun, L., and Hyeyeong, C. (2011)."Estimating the Impacts of Urban Expansion on Landscape Ecology: Forestland Perspective in the Greater Seoul Metropolitan Area."Journal of Urban Planning and Development. 137 (4): 425-437. https://doi.org/10.1061/(ASCE)UP.1943-5444.0000090.

$\begin{array}{lllll}\text { ESRI.Arc } \quad \text { GIS. } & \text { (2019). } & \text { version }\end{array}$ http://desktop.arcgis.com/en/arcmap/latest/extensions/networkanalyst/locationallocation.htm.

Fan, P., Lihua, X., Wenze, Y., and Jiquan, C. (2017). "Accessibility of public urban green space in an urban periphery: The case of Shanghai." Landscape and Urban Planning. 165, 177-192. http://dx.doi.org/10.1016/j.landurbplan.2016.11.007.

Fangying, G., Zhao-Cheng, Z., and Edward, N. (2016). "Modeling Elderly Accessibility to Urban Green Space in High Density Cities: A Case Study of Hong Kong." Procedia Environmental Sciences. 36: 90 - 97. https://doi.org/10.1016/j.proenv.2016.09.018.

Fisher, H., and Rushton, G. (1979). "Spatial efficiency of service locations and the regional development process papers." Regional Science Association. 42 (1): 83-97. https://doi.org/10.1111/j.1435-5597.1979.tb01066.x

Francisco, J., José, A., Emilio, H., Silvia, L., Jin, S., María, N., and Alejandro, R. (2017). "Network and Spatial Analysis to Assess and Guide Decisions about Equitable Accessibility to Health Services: The Public Palliative Care System in Extremadura (Spain)." Diversity and Equality in Health and Care. 14 (4): 184-192. DOI: $10.21767 / 2049-5471.1000110$.

Geurs, K. (2004). “Accessibility Evaluation of Land-Use and Transport Strategies Reviewand Research Directions.”Journal of Transport Geography. 12 (2): 127140.https://doi.org/10.1016/j.jtrangeo.2003.10.005.

Gould, P. (1969). "Spatial Diffusion.Resource Paper, 17."Association of American Geographers, Washington DC.

Greg, B., Morgan, S., and Delene, W. (2014).'Using participatory GIS to measure physical activity and urban park benefits."Landscape and Urban Planning. 121: 34-44. https://doi.org/10.1016/j.landurbplan.2013.09.006.

Haifeng, L., Wenbo, C., and Wei, H. (2015). "Planning of Green Space Ecological Network in Urban Areas: An Example of Nanchang, China" Int. J. Environ. Res. Public Health. 12 (10): 12884-12904. https://doi.org/10.3390/ijerph121012889.

Hakimi, S. (1964)."Optimum locations of switching centers and the absolute centers and medians of a graph.”Oper. Res. 12 (3): 450-459. https://www.jstor.org/stable/168125.

Hand, L., Freeman, C., Seddon, J., Stein, A., and van Heezik, Y. (2016). “A novel method for fine-scale biodiversity assessment and predictionacross diverse urban landscapes reveals 
social deprivation-relatedinequalities in private, not public spaces." Landscape and Urban Planning. 151: 33-44. https://doi.org/10.1016/j.landurbplan.2016.03.002.

Hao, Z., Po, Y., Lai, a., and Jim, Y. (2017).“'Species diversity and spatial pattern of old and precious trees in Macau."Landscape and Urban Planning. 162: 56-67. https://doi.org/10.1016/j.landurbplan.2017.02.002.

Herrera, R., Markevych, I., Berger, U., Genuneit, J., Gerlich, J., Nowak, D., Schlotz, W., Vogelberg, C., VonMutius, E., and Weinmayr, G. (2018). "Greenness and job-related chronic stress in young adults: A prospectivecohort study in Germany." Br. Med. J. Open Access. 8 (6): 1-12. http://dx.doi.org/10.1136/bmjopen-2018-021599.

Howerton, C. (2006). "GIS Network Analyses of fire department response time Dallas Texas, Course project for GEOG 4550." University of North Texas.

Hu, B., He, Y., Lu, X., and Chen, W. (2005). "Green Space Accessibility Research Based on GIS: Taking Shenyang as an Example." Journal of Shenyang Architectural and Civil Engineering Institute. 21: 671-675.

Hunadi, M. (2014). "Measuring Access to Primary Health Care: Use of a GIS-Based Accessibility Analysis, Built Environment." Council for Scientific and Industrial Research. 19-22, URI: http://hdl.handle.net/10204/7913

Imtiaz, A., Chandio, A., Matori, B., and Dano, U. (2011).“GIS-based Accessibility Analysis Using Suitable Land for Public ParksinLarkana City Pakistan."Research Journal of Applied Sciences, Engineering and Technology. 3(6): 553-557.

Javaid, A., Mudasir, M., Divya, S., and Asima, M. (2017). "Location-Allocation model applied to urban public services: Spatial analysis of fire stations in Mysore urban area Karnataka, India." International Journal of Advanced Research and Development. 2 (5): 795-801.

Jim, C. (2015). "Assessing climate-adaptation effect of extensive tropical green roofs in $\begin{array}{llll}\text { cities."Landscape } \quad \text { and Urban } & \text { 54-70. }\end{array}$ https://doi.org/10.1016/j.landurbplan.2015.02.014.

Jin, C., Lu, Q., and Fan, L. (2010). "Research on Accessibility of Scenic Spots in the Yangtze River Delta Based on Land Traffic Network."Journal of Natural Resources. 25: 258269.

Johannes, S., and Hubert, J. (2017). "National Parks and demographic change - Modelling the effects of ageing hikers on mountain landscape intra-area accessibility." Landscape and Urban Planning. 163: 32-43. https://doi.org/10.1016/j.landurbplan.2017.03.001.

Jürgen, B., and Martina, A. (2015). "Allotment Gardens Contribute to Urban Ecosystem Service: Case Study Salzburg, Austria." J. Urban Plann. Dev. 141 (3): 1-11. https://doi.org/10.1061/(ASCE)UP.1943-5444.0000264. 
Kondo, C., Jacoby, F., and South, C. (2018). "Does spending time outdoors reduce stress? A review of real-timestress response to outdoor environments."Health Place. 51: 136150. https://doi.org/10.1016/j.healthplace.2018.03.001.

LA Rosa, D. (2014). “Accessibility to Greenspaces: GIS Based Indicators for Sustainable Planning in A Dense Urban Context." Ecological Indicators. 42 (7): 122-134. https://doi.org/10.1016/j.ecolind.2013.11.011.

LA Rosa, D., and Privitera, R. (2013). "Characterization of Non-Urbanized Areas for LandUse planning of Agricultural and Green Infrastructure in Urban Contexts." Landscape and Urban Planning. 109 (1): 94-106. https://doi.org/10.1016/j.landurbplan.2012.05.012.

Li, M., and Liang, F. (2009).“Accessibility and Service of Shenyang’s Urban Parks by Network Analysis.”ActaEcologicaSinica. 29: 1554-1562.

Li, Y., Shi, T., Yan, W., and Lu, N. (2016). "Accessibility Based on Optimization of Green Space Pattern-A Case Study of Shenyang." Journal of Northwest Forestry University. 31: $285-290$.

Liisa, T., Liisa, T., Marjut, I., Niina, V., and Osmo, K. (2001)."Forest management and public perceptions visual versus verbal information."Landscape and Urban Planning. 53 (1-4): 53-70. https://doi.org/10.1016/S0169-2046(00)00137-7.

Lin, M., Hongtao, W., and Bing, L. (2019). "Convenience Analysis of Citizen Using Garden Green Space Basing on Road Network's Accessibility." Current Urban Studies. 7 (3): 311-320. DOI: 10.4236/cus.2019.73015.

Lina, B., Gaston, J., Fuller, A., Wu, D., Bush, R., and Shanahan, F. (2017). "How green is your garden?: Urban form and socio-demographic factors influence yard vegetation, visitation, and ecosystem service benefits." Landscape and Urban Planning. 157: 239246. https://doi.org/10.1016/j.landurbplan.2016.07.007.

Ma, B., and Cao, S. (2006). "A GIS-Based Evaluation Method for Accessibility of Urban Public Green Landscape."ActaScientiarumNaturaliumUniversitatisSunyatseni. $\quad 45$ : 111-115.

Ma, L., and Lu, Q. (2011). "Research on Landscape Accessibility of City Green Space Based on Traffic Network - Case Study of the Garden Green Space of the City Proper of Nanjing." Journal of Chinese Landscape Architecture. 7: 92-96.

Ma, L., Xie, Q., Shi, S., Ye, X., and Zhao, A. (2017).“Regional maldistribution of China's hospitals based on their structural system."Sustainability. 9 (6): 1-18. https://EconPapers.repec.org/RePEc:gam:jsusta:v:9:y:2017:i:6:p:1046-:d:101639.

Maas, J., Verhij, R., Groenewegen, P., De Vries, S., and Spreeuwenberg, P. (2006). "Green space, urbanity, and health: Howstrong is the relation?." J. Epidemiol. Community Health. 60 (7): 587-592., http://dx.doi.org/10.1136/jech.2005.043125. 
Mario, R., Antonio, P., and Catherine, M. (2014)."Walking accessibility to urban parks by children: A case study of Montreal."Landscape and Urban Planning. 125: 38-47. https://doi.org/10.1016/j.landurbplan.2014.02.002.

Marsh, T., and Schilling, A. (1994). "Equity measurement in facility location analysis: A review and framework." Eur, J. Oper. Res. 74 (1): 1-17. https://doi.org/10.1016/03772217(94)90200-3.

Mirchandani, B., and Francis, L. (1990). "Discrete Location Theory", John Wiley \& Sons: New York, NY, USA.1-576. https://www.wiley.com/en-us/Discrete+Location+Theory-p9780471892335.

Muge, U., Cengiz, U., and Ahmet, C. (2016). "GIS-Based Accessibility Analysis for Neighbourhood Parks: The Case of Cukurova District." Journal of Digital Landscape Architecture.46-56, 10.5194/isprs-archives-xlii-2-w1-95-2016.

Ohta, K., Takano,S., Kagaya, S., Yamada, H., Minakami, H., and Yamamura, E. (2007). "Analysis of the GeographicalAccessibility of Neurosurgical Emergency Hospitals in SapporoCity Using GIS and AHP.”International Journal ofGeographical Information Science. 21 (6): 687 - 698. https://doi.org/10.1080/13658810601135692.

Onishi, A., Cao, X., Ito, T., Shi, F., and Imura, H. (2010)."Evaluating the potential for urban heat-island mitigation by greening parking lots."Urban Forestry \& Urban Greening. 9 (4): 323-332. https://doi.org/10.1016/j.ufug.2010.06.002.

Pan, H., and Cong, B. (2012)."Spatial Accessibility of Scenic Spot at 4A Level and Above in China."Scientia Geographic Sinica. 32: 1321-1327.

Puerto, J., Ricca, F., and Scozzari, A. (2009).“Extensive facility location problems on networks with equity measures.”Discret. Appl. Math.157 (5).10691085.https://doi.org/10.1016/j.dam.2008.03.035.

Rahman, S., and Smith, D. (1996). "The efficiency of inefficiency:The deployment of health facilities in rural Bangladesh,in: M. Alauddin, S. Hasan (Eds.)." Bangladesh: Economy,People, and the Environment, Department ofEconomics, University of Queensland, Brisbane. 197-209.

Rais, A., and Viana, A. (2010). "Operations research in healthcare: A survey." Int. Trans. Oper. Res. 18 (1): 1-31, https://doi.org/10.1111/j.1475-3995.2010.00767.x.

Root, E., Silbernagel, K., and Litt, J. (2017). "Unpacking healthy landscapes: Empirical assessment of neighborhood aesthetic ratings in an urban setting." Landscape and Urban Planning. 168: 38-47. https://doi.org/10.1016/j.landurbplan.2017.09.028.

Samira, B., Alireza, V., Ali, A., and Hossein, A. (2018). "The Ordered Capacitated MultiObjective Location-Allocation Problem for Fire Stations Using Spatial Optimization.” ISPRS Int. J. Geo-Inf. 7 (2): 20-44. https://doi.org/10.3390/ijgi7020044. 
Sarel, C., Marié, d., Juaneé, C., Ernst, D., and Francois, R. (2014). "Sustainable urban landscapes: South African perspectives on transdisciplinary possibilities." Landscape and Urban Planning. 125: 260-270. doi:10.1016/j.landurbplan.2014.02.009.

Strohbach, W., Haase, D., and Kabisch, N. (2009). "Birds and the city: Urban biodiversity, land use, and socioeconomics." Ecology and Society. 14 (2): 1-15, http://www.ecologyandsociety.org/vol14/iss2/art31/.

Sturm, R., and Cohen, D. (2014)."Proximity to urban parks and mental health.”Journal of Mental Health and Policy Economics. 17: 19-24.

Tammy, D. (2004). "Location of casualty collection points."Environ. Plan. C Gov. Policy. 22 (6): 899-912. https://doi.org/10.1068/c13r.

Tammy, D., and Zvi, D. (2007).“The gravity p-median model.”Eur. J. Oper. Res. 179 (3): 1239-1251. https://doi.org/10.1016/j.ejor.2005.04.054.

Tenley, M., and Jennifer, V.(2015). "Growing a diverse urban forest: Species selection decisions by practitioners planting and supplying trees."Landscape and Urban Planning. 138: 1-10. https://doi.org/10.1016/j.landurbplan.2015.01.007.

Tratalos, J., Fuller, A., Warren, H., Davies, G., and Gaston, J. (2007). "Urban form, biodiversity potential and ecosystem services." Landscape and Urban Planning. 83 (4): 308-317. https://doi.org/10.1016/j.landurbplan.2007.05.003.

Triguero-Mas, M., Dadvand, P., Cirach, M., Martinez, D., Medina, A., Mompart, A., Xavier, B., Regine, G., and Mark, J. (2015). "Natural outdoor environments and mental and physical health: relationships and mechanisms." Environment International. 77: 35-41. https://doi.org/10.1016/j.envint.2015.01.012.

Tsou, W., Hung, T., and Chang, L. (2005).“An accessibility-based integrated measure of relative spatial equity in urban public facilities."Cities. 22 (6): 424-435. https://doi.org/10.1016/j.cities.2005.07.004.

Villeneuve, J., Jerrett, G., Su, J., Burnett, T., Chen, H., Wheeler, J., and Goldberg, S. (2012). "A cohort studyrelating urban green space with mortality in Ontario, Canada."Environ. Res. 115: 51-58, https://doi.org/10.1016/j.envres.2012.03.003.

Wei, K., and Yang, N. (2016)."Walking Reachability of Urban Public Space: Nangang District.”Harbin. Planner. 32: 93-97.

Wood, L., Hooper, P., Foster, S., and Bull, F. (2017). "Public green spaces and positive mental health-Investigatingtherelationship between access, quantity and types of parks and mental wellbeing." Health Place. 48: 63-71. https://doi.org/10.1016/j.healthplace.2017.09.002. 
Wu, H., Liu, L., Yu, Y., and Peng, Z. (2018). "Evaluation and planning of urban green space distribution based on mobile phone data and two-step floating catchment area method." Sustainability. 10 (1): 1-11, https://doi.org/10.3390/su10010214.

Wu, T., Prina, M., Jones, A., Matthews, E., and Brayne, C. (2015). "Older people, the natural environment andcommon mental disorders: Cross-sectional results from the Cognitive function and ageing study." $\mathrm{Br}$. Med. J.Open Access. 5 (9): 1-9. http://dx.doi.org/10.1136/bmjopen-2015-007936.

Yasenovskiy, V., and Hodgson, J. (2007)."Hierarchical location-allocation with spatial choice interaction modelling."Ann. Assoc. Am. Geogr. 97 (3): 496-511. https://doi.org/10.1111/j.1467-8306.2007.00560.x.

Yin, H. (2008).“Urban Open Space-Pattern, Accessibility and Agreeable."Nanjing: Southeast University Press.

Yin, H., and Xu, J. (2009)."Measuring the Accessibility of Parks: A Case Study in Shanghai, China."2009 Sixth International Conference on Fuzzy Systems and Knowledge Discovery, Shanghai. China. DOI: 10.1109/FSKD.2009.583.

Yin, H., Kong, H., and Zong, G. (2008).“Accessibility and Equity Assessment on Urban Green Space.”ActaEcologicaSinica. 28: 3375-3383.

Yuhong, T., and Jim, Y. (2011). "Factors influencing the spatial pattern of sky gardens in the compact city of Hong Kong." Landscape and Urban Planning. 101 (4): 299-309. https://doi.org/10.1016/j.landurbplan.2011.02.035.

Zhong, X., Fu, Y., and Feng, H. (2016).“The Accessibility patterns and City Types Based on Passenger Rail Transport in China."Resources and Environment in the Yangtze Basin. 25: 1645-1653.

Zhou, G., and Guo, Z. (2004).'GIS-Based Researches on Urban Green Space on Landscape Gravity Field with Ningbo City as an Example."ActaEcologicaSinica. 24: 1157-1163.

Zhu, X., Liu, S., and Yeow, M. (2005).“A GIS-Based Multi- Criteria Analysis Approach to Accessibility Analysis for Housing Development in Singapore."Proceedings of SSC Spatial Intelligence, Innovation and Praxis: The national biennial Conference of the Spatial Sciences Institute, Melbourne. 